\title{
Ultimate strength characteristics of as-built ultra-large containership hull structures under combined vertical bending and torsion
}

\author{
Dong Hun Lee ${ }^{\mathrm{a}}$ and Jeom Kee Paik ${ }^{\mathrm{a}, \mathrm{b}, \mathrm{c}^{*}}$ \\ ${ }^{a}$ Department of Naval Architecture and Ocean Engineering, Pusan National \\ University, Busan 46241, South Korea \\ ${ }^{b}$ The Korea Ship and Offshore Researech Institite (The Lloyd's Register Foundation \\ Research Centre of Excellence), Pusan National University, Busan 46241, South \\ Korea \\ ${ }^{c}$ Department Mechanical Engineering, University College London, London WC1E \\ 7JE, $U K$ \\ *Corresponding author. J.K. Paik. (Email) j.paik@ucl.ac.uk
}

\begin{abstract}
The aim of the present paper is to investigate the ultimate strength characteristics of as-built ultra-large containership hull structures under combined vertical bending and torsional moments with varying the ship size. The intelligent supersize finite element method (ISFEM) is employed for the ultimate hull girder strength analyses. A total of three as-built containerships carrying 9,300 TEU, 13,000 TEU, and 22,000 TEU are studied. Based on the computations, ultimate strength interaction relationships of containership hull girders under combined vertical bending and torsional moments are also formulated by a curve fitting. Insights and structural design recommendations obtained from the study are summarized, which will be useful to not only enhance the ultimate limit state capacity of containership hull structures in existing sizes but also achieve the robust structural design of ultra-larger containerships which have never been built before.
\end{abstract}

Keywords: Ultra-large containerships; Ultimate hull girder strength; Combined vertical bending and torsional moments; Intelligent supersize finite element method (ISFEM); Ultimate strength interaction relationship

\section{Introduction}

In the shipping industry, containerships carrying more than 10,000 TEU belong to the very-large containership (VLCS) class. Over the last decade, containership size has continued to increase substantially driven by economic need, as shown in Figure 1, and ultra-large containerships (ULCS) carrying 22,000 TEU have appeared. Technical challenges are pertinent in association with the structural safety and integrity of ultra-large containerships under extreme conditions and accidents as structural failures of containerships followed by total loss or catching fire before sinking have rarely happened, as shown in Figure 2 (Schuler 2018). It is reportedly recognized that the hull structures of the MOL Comfort were failed by the action of extreme hull girder loads while in operation in the Indian Ocean in June 2013 (ClassNK 2014). 
In contrast to oil tankers without deck openings where the effects of torsional moments are often negligible, containerships have large deck openings that reduce the torsional rigidity of the entire ship hull structure, and the hull girder collapse of ultra-large containerships under combined vertical bending and torsional moments is a primary concern. The structural design concept of a torsion box is applied to increase the torsional rigidity of containership hull structures where very thick plates are mounted in the corners of deck openings (Hughes and Paik 2013). Classical theory tells that both shear and warping stresses developed in a box girder due to torsion can of course affect the bending response (Vlasove 1959).

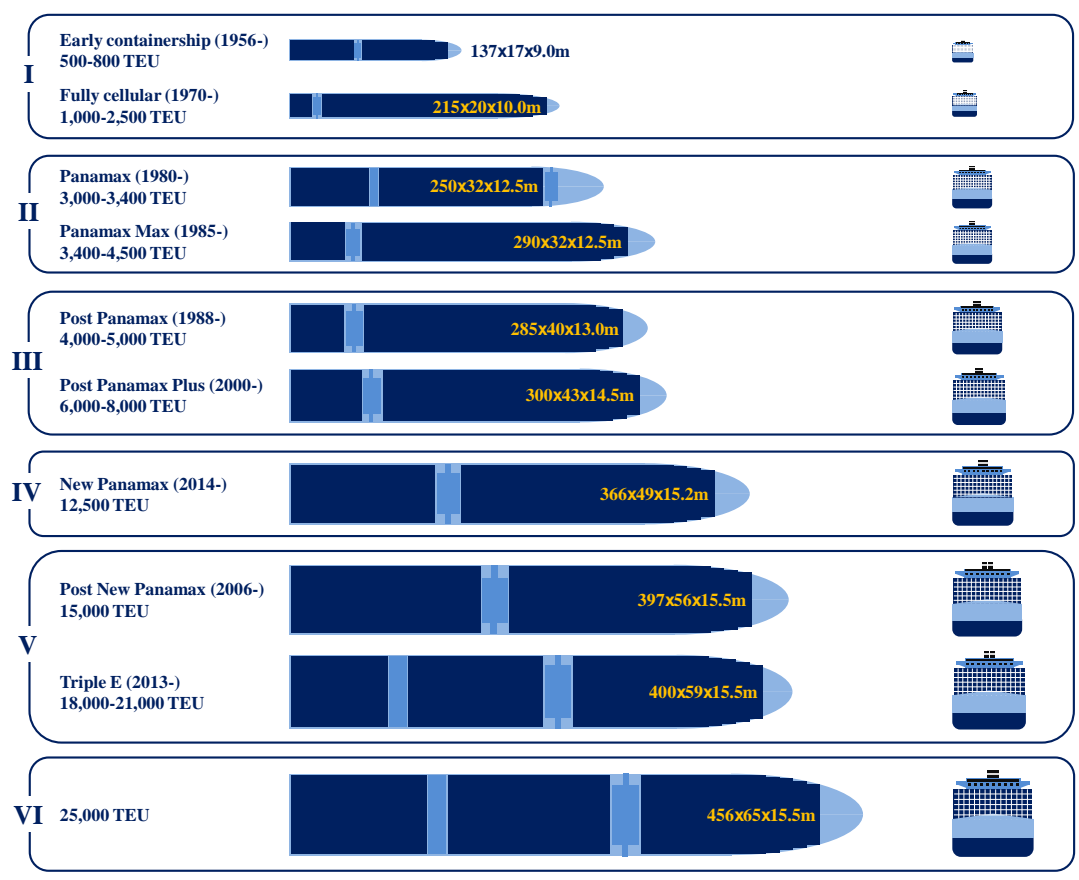

Figure 1. Changes in containership size (Paik 2015).
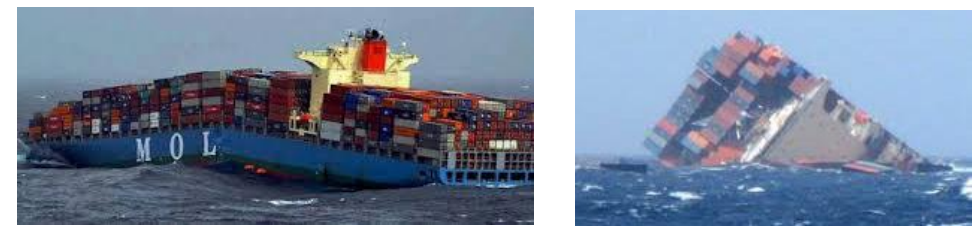

(a) MOL Comfort accident with hull girder collapse followed by sinking, occurred in June 2013

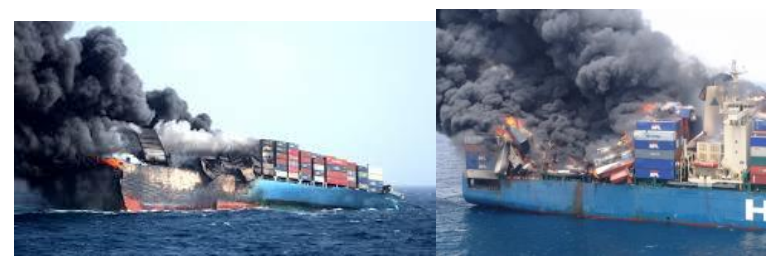

(b) Hyundai Fortune accident with fire caught after structural failure, occurred in March 2006

Figure 2. Examples of accidents involving containerships (Schuler 2018). 
A historical review of the studies on the ultimate strength of box girders or ship's hull structures under combined bending and torsion may be worth: In the 1980s, the works of the Ostapenko group raised an important issue that torsion can reduce the longitudinal strength of a ship with a large deck opening when the vessel travels in oblique seas with high waves (Ostapenko and Vaucher 1980, Ostapenko 1981, Ostapenko and Moore 1982). Pedersen (1991) developed beam theory to analyze the torsional bending response of a ship hull. Paik et al. (2001) investigated the ultimate strength characteristics of a 4,300 TEU containership hull under combined vertical bending and torsion, realizing that torsion is not a sensitive component for the ultimate vertical bending moment in a normal operation but the ultimate strength of ship hulls with low torsional rigidity can be affected significantly when torsional moment is relatively large. Sun and Guedes Soares (2003) performed a small scale physical model testing on the ultimate torsional strength of a ship-type box girder, showing that the structural design of ships with a large deck opening using the initial yielding criteria may be too conservative. Tanaka et al. (2015) conducted the ultimate strength tests on three 1/13-scale hull models under combined vertical bending and torsion, showing that the torsion can significantly reduce the ultimate hull girder bending capacity. Syrigou and Dow (2018) derived the formulations of the stress-strain relationships for plates under combined shear and compression/tension which can be used for the ultimate hull girder strength analysis under the corresponding combined loads. Paik (2018) presented a complete set of the analytical formulations for the stress-strain relationships of plates under combined biaxial compression/tension, edge shear and lateral pressure loads before and after the ultimate strength is reached. Alfred Mohammed et al. (2016) and Wang et al. (2019) studied the ultimate hull strength characteristics of a 10,000 TEU containership under vertical bending and torsion using nonlinear finite element method, showing that the ultimate hull girder bending capacity can be reduced significantly by large torsional moments.

It is now well recognized that limit states and risks are the best criteria for the safety analysis and design of structures and infrastructures (Paik 2018, 2019). Analytical methods of structural mechanics are available to calculate the ultimate hull girder strength of ships which can be modeled as a box girder. Caldwell (1965) is one of the pioneers who suggested an analytical method to predict the ultimate hull girder strength under a vertical bending moment. He made a presumption of a longitudinal stress distribution over the hull cross section at the ultimate limit state, where all of the tensioned parts yield and all of the compressed parts buckle and collapse. The ultimate hull girder strength can then be calculated by integrating the first moment based on this presumed stress distribution. Caldwell's approach was modified by Paik and Mansour (1995) to consider the realistic longitudinal stress distribution over a hull cross section because the longitudinal stresses in the vicinity of the neutral axis are linearly elastic without any yielding or buckling. A further modification to the PaikMansour approach was suggested to reflect the effect of vertical members close to the tension flange that may have yielded (Paik et al. 2012). However, analytical methods are primarily applied to the calculation of ultimate hull girder strength under a pure bending moment. 
The nonlinear finite element method (NLFEM) is now well recognized as one of the most powerful methods to calculate ultimate hull girder strength (Rutherford and Caldwell 1990, Paik et al. 2008a, 2008b, 2008c, Hughes and Paik 2013, Mohammed et al. 2016, Paik 2018, Wang et al. 2019). NLFEM overcomes the constraints of analytical methods, although it requires enormous computational effort to generate the finite element model and to simulate the nonlinear analysis of large-sized structures.

To reduce the computational cost without loss of accuracy, special-purpose finite elements have to be adopted. The Ueda group (Ueda and Rashed 1974, 1984, 1991, Ueda et al. 1983, 1984, 1986a, 1986b) developed the idealized structural unit method (ISUM) using the matrix technique together with closed-form expressions of nonlinear local member behavior based on analytical solutions. In almost parallel effort, Smith (1977) suggested a similar approach to the ISUM, where a ship's hull girder is modeled as an assembly of plate-stiffener combination models of which behavior is formulated in terms of the stress-strain relationships using NLFEM computations. The ISUM and Smith's method are very useful for calculating the ultimate hull girder strength under a pure vertical bending moment, but it is difficult to employ them to calculate the ultimate hull strength under combined bending and torsional moments. Furthermore, these two approaches are limited to use for a single sliced-hull section between two adjacent transverse frames which are modeled to follow simply supported conditions. It is however obvious that the bending and torsional rigidities of transverse frames are finite so that they may deform or deflect even before the ultimate hull girder limit state is reached. Therefore, it is desirable to include transverse frames in the extent of analysis by allowing their deformation during the hull girder loading until and after the ultimate limit state is reached.

To resolve the technical issues associated with the ISUM and Smith's method, Paik proposed the intelligent supersize finite element method (ISFEM) to simulate the nonlinear responses of plated structures in large size under a general set of combined load components (Hughes and Paik 2013, Paik 2018). The ISFEM employs the conventional NLFEM modeling technique in the formulation of structural stiffness equations but uses intelligent supersize elements where the stress-strain relationships or the [D] matrices of ISFEM elements are formulated by analytical solutions as a function of applied stresses, by taking into account the effects of buckling and plastic collapse. Details of formulating the stress-strain relationships for plates under combined biaxial, shear and lateral pressure loads by taking account of initial imperfections in the form of initial deflection and residual stress are presented depending of the status of failures (Paik 2018). The theory of ISFEM has been implemented in the ALPS/HULL computer program for the progressive hull girder strength analysis of ships (ALPS/HULL 2018, ALPS/HULL3D 2019) which employs the ALPS/ULSAP program as a module for the ultimate strength analysis of plates and stiffened panels (ALPS/ULSAP 2019). The validity of the ALPS/HULL programs has been confirmed by comparison with NLFEM or physical model test data, e.g., Dow (1991).

The aim of this study is to investigate the ultimate strength characteristics of as-built containership hull structures under combined vertical bending and torsional 
moments with varying ship sizes. For this purpose, a total of three as-built containerships carrying 9,300 TEU, 13,000 TEU, and 22,000 TEU are studied. ALPS/HULL3D program (2019) is employed to compute the progressive collapse behavior of the ship hull structures. Based on the computations, the ultimate hull girder strength relationships between vertical bending and torsional moments are also empirically formulated.

\section{Method for the ultimate hull strength analysis}

\subsection{ALPS/HULL3D Program}

The ALPS/HULL3D (2019) program using ISFEM is employed where transverse frames of hull structures are included with actual geometric and material properties in the extent of the analysis, instead of presuming that they provide simply supported boundary conditions. Each of all plating surrounded by support members (e.g., stiffeners) is modeled using an ISFEM rectangular plate element which has four nodal points in the corners. Each node has six degrees of freedom associated with three translational components and three rotational components, as shown in Figure 3.

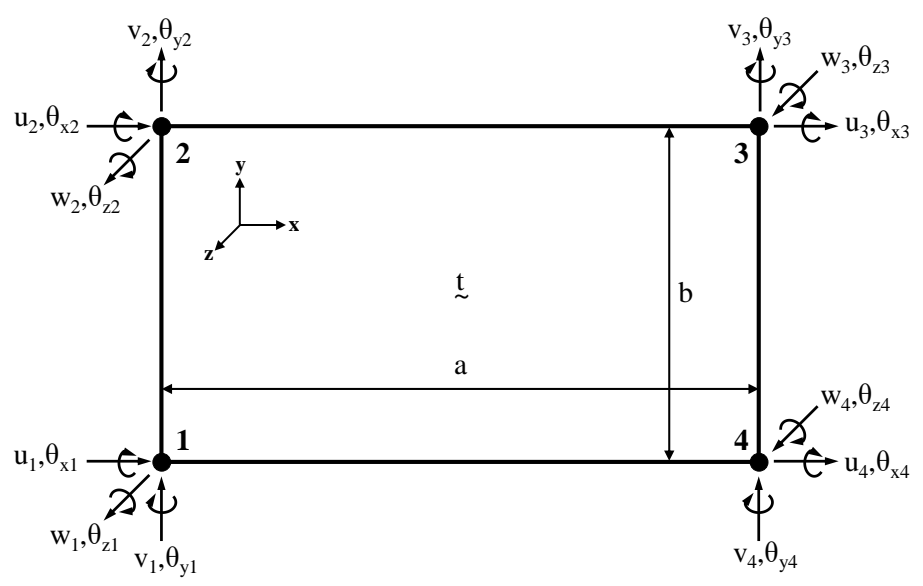

Figure 3. Six degrees of freedoms at each of four corner nodal points for an ISFEM rectangular plate element (Paik 2018).

\subsection{Material and geometric modeling}

The material properties of the plate elements are $E$ in elastic modulus, $v$ in Poisson's ratio and $\sigma_{Y}$ in yield strength. The elastic-perfectly plastic material model without considering strain-hardening effect is applied. The dimension of the ISFEM plate element is $a$ long, $b$ wide and $t$ thick.

Unlike the traditional NLFEM plate elements, the ISFEM plate elements must be surrounded by support members (e.g., stiffeners) at four edges. However, some plating such as angle- or T-type stiffener flange are supported at three edges while one edge is free, but such plating is still modeled using the plate element although the 
stress-strain relationship and the failure status should take into account the effect of the corresponding edge conditions.

Figure 4 shows the mid-ship hull section drawing for the 1/3-scale frigate hull model tested by Dow (1991). Figure 5 presents the ALPS/HULL3D model of the Dow test hull, having a 2-bay hull girder section which includes one transverse frame between two hull girder sections. A total of 944 ISFEM rectangular plate elements are used for plating between stiffeners, stiffener webs and stiffener flanges.

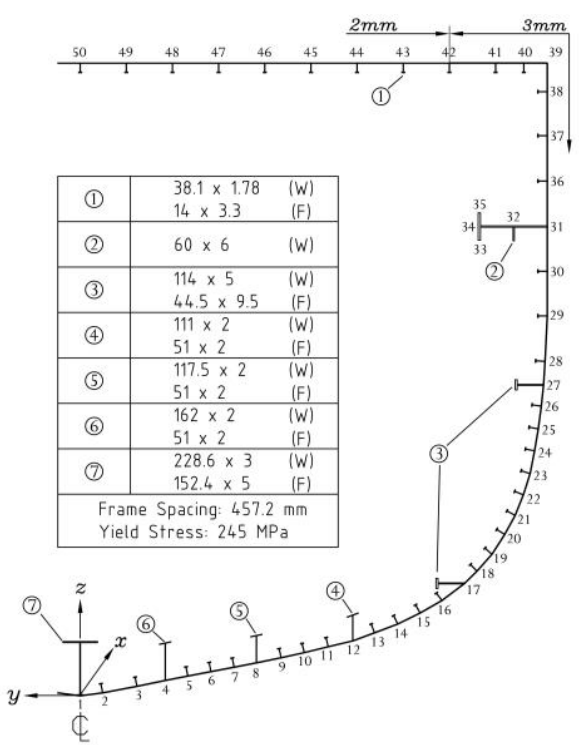

Figure 4. Mid-ship hull section drawing of the 1/3-scale frigate hull model tested by Dow (1991).

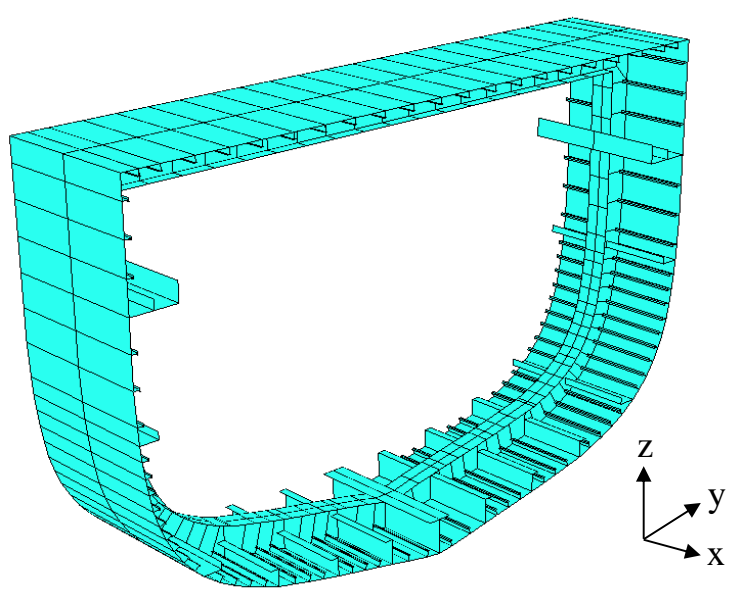

Figure 5. The ALPS/HULL3D model for the Dow's $1 / 3$-scale frigate test hull structure using a total of 944 ISFEM plate elements.

\subsection{Modeling of welding-induced initial imperfections}

Effects of welding-induced initial imperfections need to be considered for the ultimate strength analysis, and useful techniques for modeling the initial imperfections are available in the literature (Hughes and Paik 2013, Yao and Fujikubo 2016, Paik 2018). The strength reduction characteristics differ for different shapes and amplitudes of 
initial imperfections (Paik et al. 2004). Illustrative examples for modeling the initial imperfections are now presented in association with the Dow's test hull structure.

The shape and magnitude of the plate initial deflection may be modeled so as to present them by the following expression.

$$
w_{o}=w_{o p l} \sin \frac{m \pi x}{a} \sin \frac{\pi y}{b}
$$

where $w_{o}$ is the plate initial deflection, $w_{o p l}$ is the amplitude of the initial plate deflection, $m$ is the buckling half-wave number in the plate length (long) direction which can be determined as an integer satisfying the condition of $a / b \leq \sqrt{m(m+1)}$, while the buckling half-wave number in the breadth (short) direction is unity (1), $a$ is the plate length, and $b$ is the plate breadth.

Once the measurement database of plate initial deflections for the target structure is available, $w_{o p l}$ can be defined, or simple formulations can be used for predicting plate initial deflections (Paik 2018). The measurement database for the Dow's test hull may give as $w_{\text {opl }}=0.1 t$. A lot more complex expression than Equation (1) can of course be used as necessary.

Welding-induced residual stresses are developed in both longitudinal and transverse directions of plating as support members are attached to the plating by welding in the two directions, and their distribution in each direction can be modeled with both tensile and compressive residual stress blocks, the latter being associated with buckling and plastic collapse of plating. For the purpose of simplicity, the compressive residual stress block in the longitudinal direction is considered for the ultimate hull girder strength analysis, while that in the transverse direction is often neglected. The magnitude of the compressive residual stress block for plating of the Dow's test hull structure is assumed to be $10 \%$ of the material yield stress or $0.1 \sigma_{Y}$. In case with which the compressive residual stress block in the transverse direction is concerned, Chapter 1 of Paik (2018) may be referred to.

The initial distortions of stiffeners can be grouped into the column-type initial distortion, $w_{o c}$, and the sideways initial distortion, $w_{o s}$ (Paik 2018). For the Dow's test hull, the maximum magnitudes of initial distortion for stiffeners are presumed as follows:

$$
w_{o s}=w_{o c}=0.0015 a
$$

\subsection{Boundary conditions}

Figure 6 presents the boundary conditions for the ALPS/HULL3D hull model. One end of the model is fully fixed, whereas the other end is free to load external forces or 
displacements. For the ultimate strength analysis of the Dow's test hull, nodal displacements are incrementally applied until and after the ultimate limit state is reached.

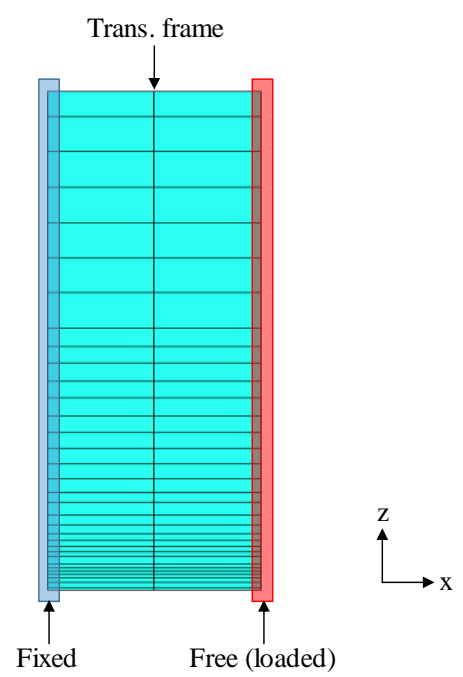

Figure 6. Boundary conditions applied for the ALPS/HULL3D hull model.

\subsection{Hull girder load applications}

\subsubsection{Vertical bending moments}

Vertical bending moments, $M_{V}$ are generated as shown in Figure 7, where nodal forces or displacements depending on hogging or sagging are incrementally applied at the cross section of the loaded end with respect to the neutral axis so that the associated hull cross section remains in-plane. The rotational angle or bending curvature is subsequently proportional to the inclination of the hull cross section. It is obvious that the position of the neutral axis shall change as local buckling or plasticity takes place and expands. The application of external forces or displacements shall then be applied with respect to the new or updated position of the neutral axis at each incremental step of load application. The distance $g$ measured from the baseline (reference position) to the horizontal neutral axis of the hull cross section can be calculated as follows (Paik 2018):

$$
g=\frac{\sum_{i=1}^{n}\left|\sigma_{x i}\right| a_{i} z_{i}}{\sum_{i=1}^{n}\left|\sigma_{x i}\right| a_{i}}
$$

where $\sigma_{x i}$ is the longitudinal stress of the $i$ th ISFEM plate element, $a_{i}$ is the cross-sectional area of the $i$ th ISFEM plate element, $z_{i}$ is the distance from the 
baseline to the neutral axis of the $i$ th ISFEM plate element, and $n$ is the total number of the ISFEM plate elements.

The lateral pressure loads arising from cargoes and external water pressure can affect the ultimate hull girder strength behavior (Kim et al. 2013, Paik 2018). However, the effect of lateral pressure loads is not considered in the present study.

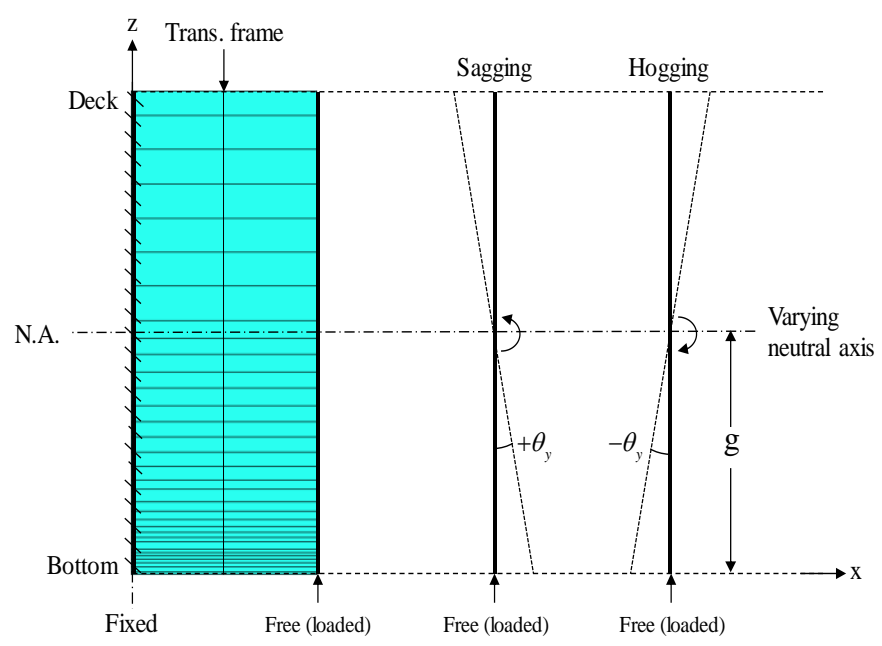

Figure 7. Application of vertical bending moments in the ALPS/HULL3D hull model.

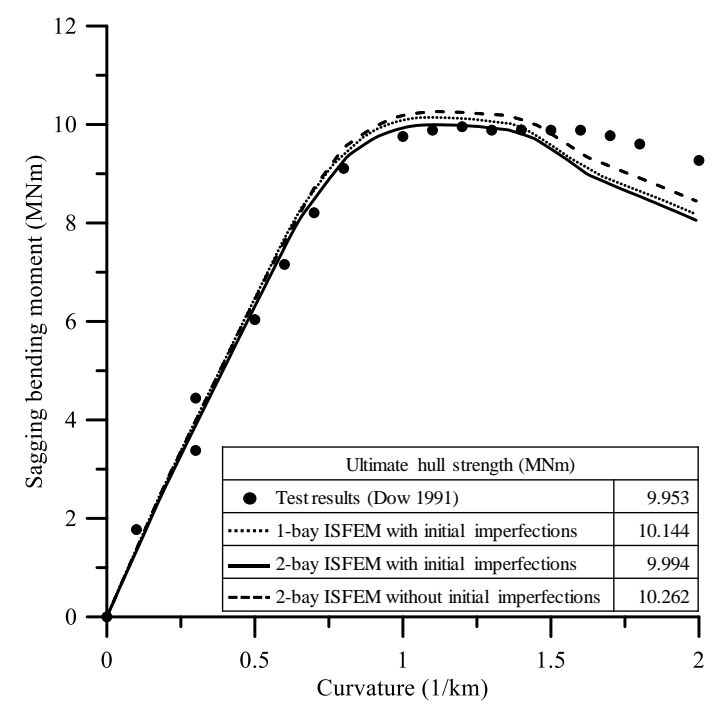

Figure 8. Comparison of the progressive collapse behavior of the Dow 1/3-scale frigate test hull under a vertical sagging bending moment.

Figure 8 shows the comparison results of the ultimate strength behavior between the experiment and the ALPS/HULL3D hull model. The effects of initial imperfections on the ultimate strength behavior are studied in the ALPS/HULL3D computations. It is shown from Figure 8 that the effects of initial imperfections cannot be neglected and also the 2-bay hull model with one transverse frame shows a slightly better agreement with the experimental results than the 1-bay model. This implies that the 1-bay hull model may be good enough to apply as far as vertical bending moments 
are predominant. However, the present study applies the 2-bay hull model to take into account the effect of transverse frames on the ultimate hull girder strength under combined vertical bending and torsion.

\subsubsection{Torsional moments}

Torsional moments are generated by a pair of horizontal nodal forces $F_{H}$ and a pair of vertical nodal forces $F_{V}$, which are applied at the corners of hull structures, as shown in Figure 9. In this case, the following condition shall be satisfied to fulfill the equilibrium of forces:

$$
F_{H} D=F_{V} B
$$

where $D$ is the depth of the hull and $B$ is the breadth of the hull. Equation (4) ensures under the Bernoulli-Euler hypothesis for a beam that the hull cross-section at the loaded end remains in plane during the action of torsion (Paik 2018). In the ALPS/HULL3D model, the center of torsional moment is positioned at the center of hull cross-section as studied by Mohammed et al. (2016) and Wang et al. (2018). Additionally, a rigid "hard cross-section plate" can be attached to the hull cross-section at the loaded end to deal with keeping it in plane during the action of torsion. The torsional moment can then be calculated as follows:

$$
M_{T}=F_{H} \text { D } \quad F_{V}
$$

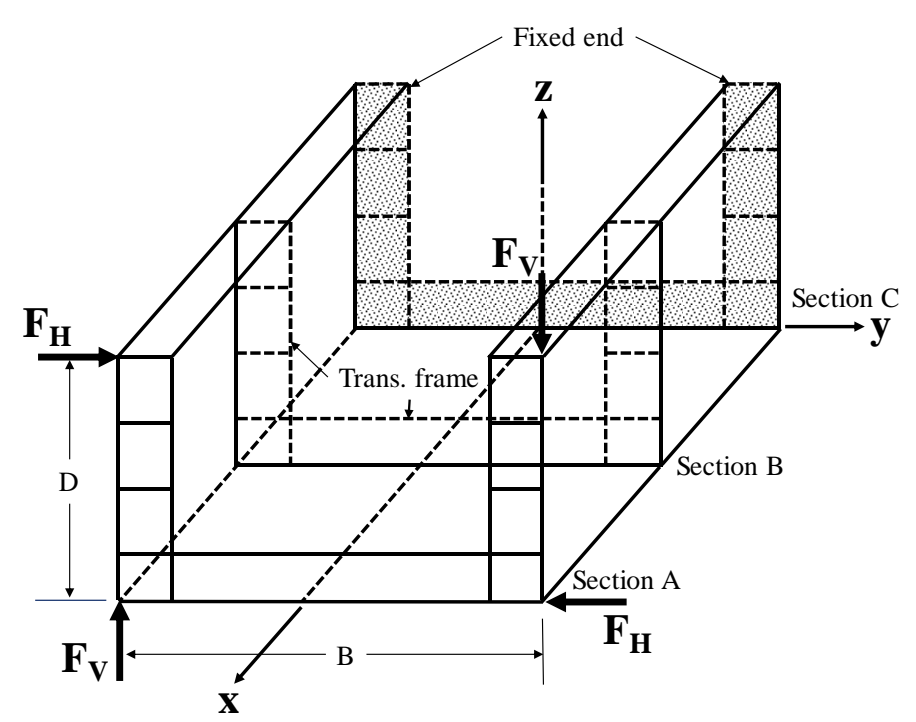

Figure 9. Application of torsional moments in the APLS/HULL3D hull model.

\subsubsection{Combined vertical bending and torsional moments}

The ultimate strength of a ship's hull under a combination of hull girder load components such as vertical and horizontal bending moments, shear forces, and torsional moments can be calculated numerically either by applying all load 
components simultaneously until one of the hull girder load components reaches its ultimate limit state or by applying one or more hull girder load components incrementally until the ultimate limit state is reached, with the rest of the load components at certain constant desired magnitudes (Hughes and Paik 2013).

Figure 10 shows various loading paths to achieve a target load combination. In linear structural mechanics, the structural responses by individual load components satisfy the principle of linear superposition, regardless of the load path. This principle can be applied to static nonlinear structural problems with a focus on buckling or ultimate strength (Hughes and Paik 2013).

In the ALPS/HULL3D model, combined vertical bending and torsional moments are incrementally applied following loading path $\mathrm{C}$ as shown in Figure 10. The loading path is determined under the assumption that the ultimate strength of hull girder is dominated by the vertical bending moments. In a real situation, the vertical bending and torsional moments may increase simultaneously, but the time gradients of each load component can be different each time according to specific sea states. Thus, the loading path $\mathrm{C}$ is adopted for the purpose of the present study and the usability for the application of combined load components. First, the torsional moment is incrementally increased until a desired magnitude is achieved. In the next round, vertical bending moments with constant ratios of bending curvatures are increased until and after the ultimate strength is reached. The internal stresses and displacements produced by the previous load application of torsional moments shall be accumulated, contributing to the change in stiffness and strength of the structure under subsequent load applications.

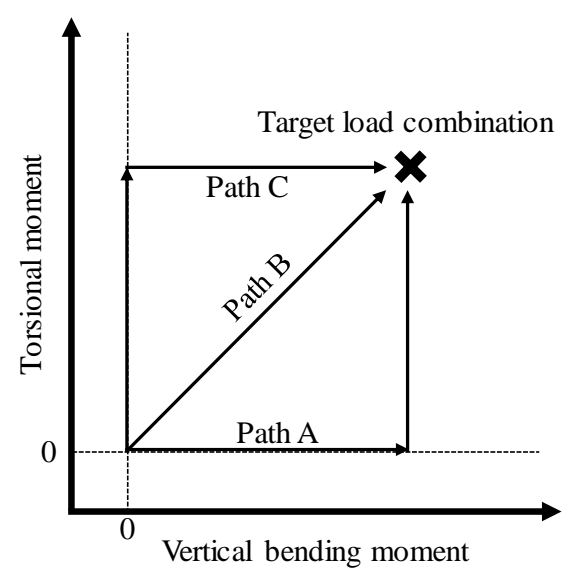

Figure 10. Various loading paths to achieve a target load combination.

\section{Ultimate strength characteristics of as-built containership hulls}

\subsection{Scantlings of as-built containerships}

A total of three as-built containerships carrying 9,300 TEU, 13,000 TEU, and 22,000 TEU are selected. Figure 11 shows the mid-ship hull section designs of the ships. Longitudinal strength members should be continuous at least along $0.15 \mathrm{~L}$ amidship (Hughes and Paik 2013). Hatch coamings of as-built containerships considered in the 
paper are arranged at cargo hold only, and thus they are not included in the ALPS/HULL3D model. The 22,000 TEU containership has the distinct torsion boxes on the upper side-shells, although both the 9,300 TEU and 13,000 TEU containerships do not accommodate the torsion boxes but instead very thick high-tensile steel plating is mounted at the upper deck to enhance the torsional rigidity of the hull cross-section. Table 1 presents the details of structural scantlings for the ships. The hull structures of the ships are made of mild steel (MS) and high-tensile steel (AH, DH and EH), as shown in Figure 11. Table 2 presents the mechanical properties of the materials.

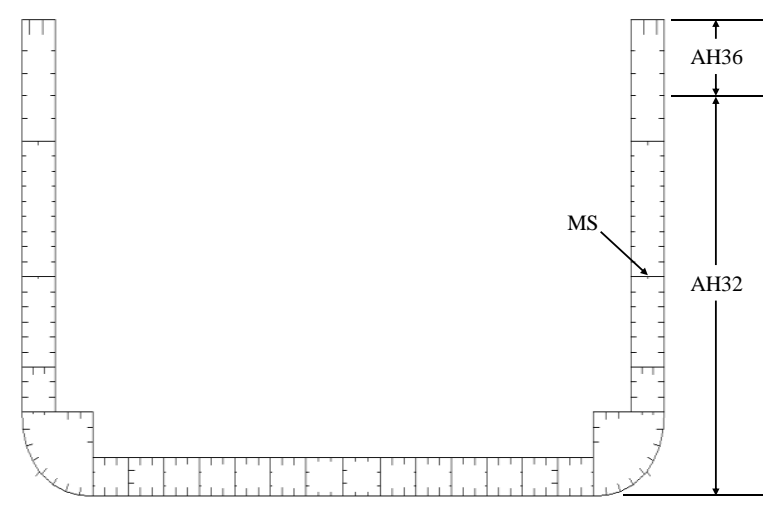

(a) As-built 9,300 TEU containership

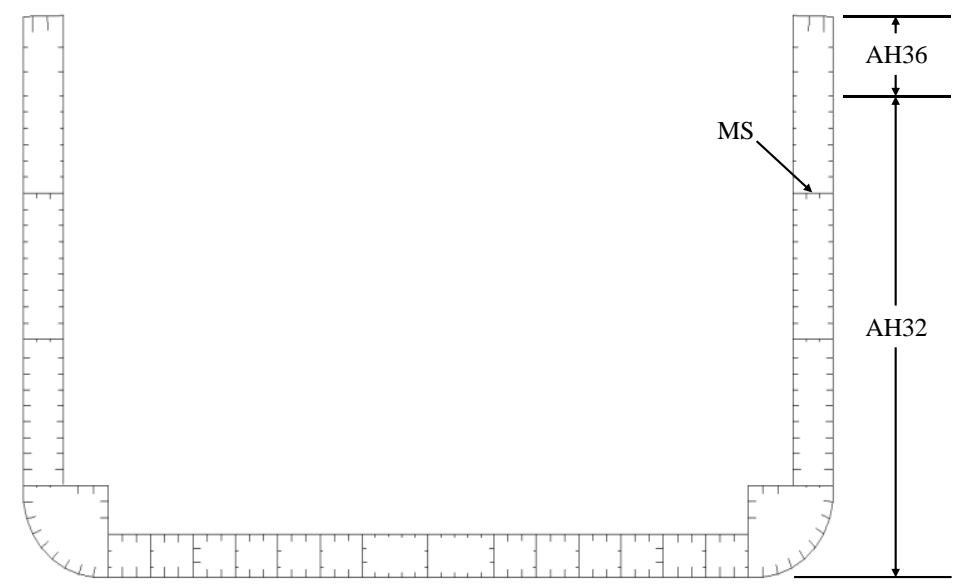

(b) As-built 13,000 TEU containership 




(c) As-built 22,000 TEU containership

Figure 11. Mid-ship section designs of the three as-built containerships.

Table 1. Structural scantlings of the three as-built containerships.

\begin{tabular}{|l|l|l|l|}
\hline Parameter & $9,300 \mathrm{TEU}$ & $13,000 \mathrm{TEU}$ & $22,000 \mathrm{TEU}$ \\
\hline $\begin{array}{l}\text { Length between } \\
\text { perpendiculars }\left(L_{B P}\right)\end{array}$ & $286.0 \mathrm{~m}$ & $366.0 \mathrm{~m}$ & $413.0 \mathrm{~m}$ \\
\hline Breadth $(B)$ & $45.6 \mathrm{~m}$ & $48.2 \mathrm{~m}$ & $58.6 \mathrm{~m}$ \\
\hline Depth $(D)$ & $27.3 \mathrm{~m}$ & $29.85 \mathrm{~m}$ & $35.1 \mathrm{~m}$ \\
\hline Scantling draft $\left(\mathrm{d}_{\mathrm{s}}\right)$ & $14.0 \mathrm{~m}$ & $15.0 \mathrm{~m}$ & $16.5 \mathrm{~m}$ \\
\hline Design draft $\left(\mathrm{d}_{\mathrm{d}}\right)$ & $12.5 \mathrm{~m}$ & $13.5 \mathrm{~m}$ & $14.5 \mathrm{~m}$ \\
\hline Block coefficient $\left(\mathrm{C}_{\mathrm{b}}\right)$ & 0.69 & 0.70 & 0.78 \\
\hline Design speed & $25.0 \mathrm{knot}$ & $25.0 \mathrm{knot}$ & $24.0 \mathrm{knot}$ \\
\hline Cross-sectional area & $6.57 \mathrm{~m}^{2}$ & $7.19 \mathrm{~m}^{2}$ & $9.22 \mathrm{~m}^{2}$ \\
\hline $\begin{array}{l}\text { Height of neutral axis } \\
\text { from bottom base line }\end{array}$ & $10.63 \mathrm{~m}^{2}$ & $11.43 \mathrm{~m}$ & $13.50 \mathrm{~m}$ \\
\hline $\begin{array}{l}\text { Moment of inertia } \\
\text { (vertical) }\end{array}$ & $719.01 \mathrm{~m}^{4}$ & $947.59 \mathrm{~m}^{4}$ & $1607.13 \mathrm{~m}^{4}$ \\
\hline $\begin{array}{l}\text { Section modulus at } \\
\text { bottom }\end{array}$ & $67.64 \mathrm{~m}^{3}$ & $82.87 \mathrm{~m}^{3}$ & $119.09 \mathrm{~m}^{3}$ \\
\hline Section modulus at deck & $43.13 \mathrm{~m}^{3}$ & $51.46 \mathrm{~m}^{3}$ & $81.98 \mathrm{~m}^{3}$ \\
\hline
\end{tabular}

Table 2. Mechanical properties of materials.

\begin{tabular}{|l|l|l|l|l|}
\hline \multirow{2}{*}{ Material } & \multicolumn{4}{|c|}{ Mechanical properties } \\
\cline { 2 - 5 } & $\begin{array}{l}\text { Density } \\
\left(\text { ton } / \mathrm{m}^{3}\right)\end{array}$ & $\begin{array}{l}\text { Elastic modulus, } \\
E(\mathrm{GPa})\end{array}$ & $\begin{array}{l}\text { Poisson's } \\
\text { ratio, } v\end{array}$ & $\begin{array}{l}\text { Yield stress } \\
(\mathrm{MPa}), \sigma_{Y}\end{array}$ \\
\hline MS & 7.85 & 205.8 & 0.3 & 235 \\
\hline
\end{tabular}




\begin{tabular}{|l|l|l|l|l|}
\hline AH32 & 7.85 & 205.8 & 0.3 & 315 \\
\hline AH36 & 7.85 & 205.8 & 0.3 & 355 \\
\hline AH40 & 7.85 & 205.8 & 0.3 & 390 \\
\hline EH36 & 7.85 & 205.8 & 0.3 & 355 \\
\hline EH40 & 7.85 & 205.8 & 0.3 & 390 \\
\hline DH32 & 7.85 & 205.8 & 0.3 & 315 \\
\hline
\end{tabular}

\subsection{As-built 9,300 TEU containership}

\subsubsection{Under pure vertical bending moment}

Figure 12 presents the ALPS/HULL3D model for the 9,300 TEU containership hull using 1,556 ISFEM plate elements. Figure 13 shows the progressive collapse behavior of the hull structure under pure vertical bending moments in hogging or sagging. The first failure moments associated with local buckling or yielding are also investigated. It is found that the first failure of the hull by yielding occurs at the deck panels in hogging at a vertical bending moment of $16.13 \mathrm{GNm}$. The hull reaches the ultimate limit state, $M_{V u, H o g}$ at a vertical bending moment of $17.89 \mathrm{GNm}$ after buckling collapse of the outer bottom panels took place. In sagging, buckling collapse first occurs on the deck panels at a vertical bending moment of $15.21 \mathrm{GNm}$, and the ultimate limit state, $M_{V u, S a g}$ is reached at a vertical bending moment of $15.40 \mathrm{GNm}$ even before the bottom panels yield.

Table 3 indicates the safety margin of the 9,300 TEU containership hull under the vertical bending moments. The design value of the total hogging bending moment (i.e., the sum of still-water and wave-induced bending moments) at the full load condition is $12.61 \mathrm{GNm}$, as determined from the IACS UR-S11A standard (IACS 2015). The safety margin of the hull is therefore given as $17.89 / 12.61=1.42$ for the ultimate hull girder strength, but it is $16.13 / 12.61=1.28$ for the first failure event,.

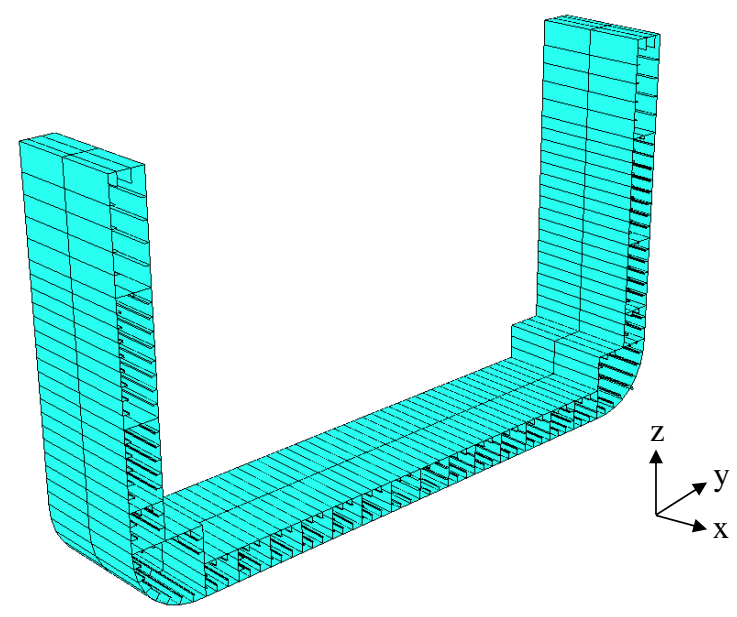

Figure 12. ALPS/HULL3D model for the 9,300 TEU containership hull using 1,556 ISFEM plate elements. 


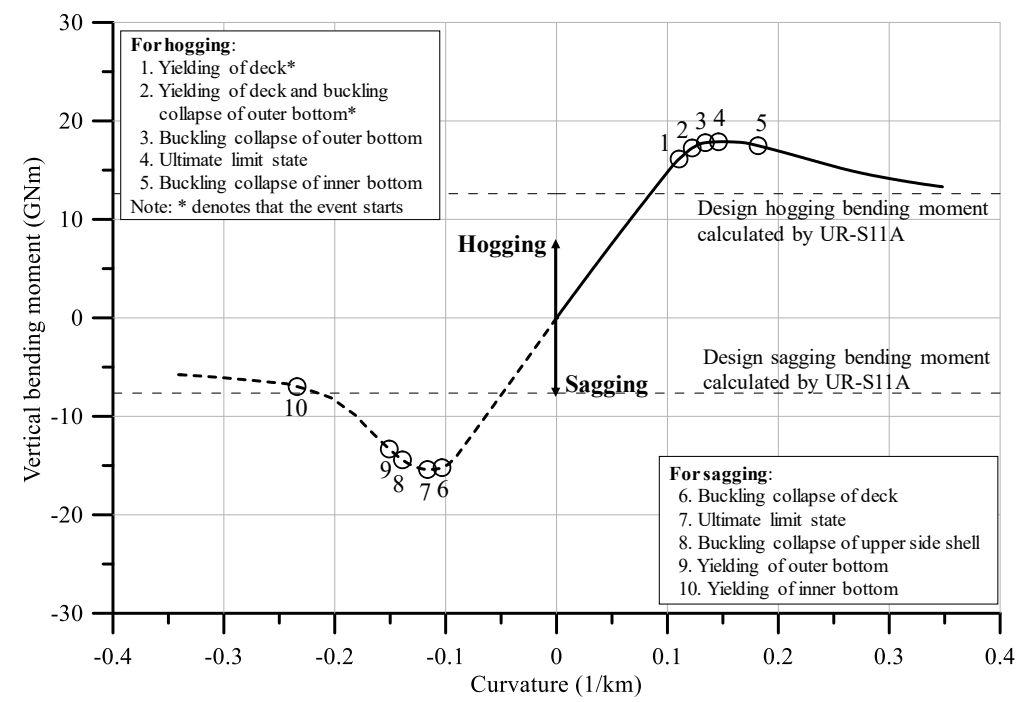

Figure 13. Progressive collapse behavior and failure modes of the 9,300 TEU containership hull under pure vertical bending moments.

Table 3. Safety margin of the 9,300 TEU containership hull under pure vertical bending moments.

\begin{tabular}{|l|l|l|l|}
\hline $\begin{array}{l}\text { Loading } \\
\text { condition }\end{array}$ & $\begin{array}{l}\text { Design } \\
\text { load }\end{array}$ & $\begin{array}{l}\text { Ultimate strength / Safety } \\
\text { margin }\end{array}$ & $\begin{array}{l}\text { First failure moment / } \\
\text { Safety margin }\end{array}$ \\
\hline Hogging & $\begin{array}{l}12.61 \\
\text { GNm }\end{array}$ & $17.89 \mathrm{GNm} / 1.42$ & $16.13 \mathrm{GNm} / 1.28$ \\
\hline Sagging & $\begin{array}{l}7.64 \\
\text { GNm }\end{array}$ & $15.40 \mathrm{GNm} / 2.02$ & $15.21 \mathrm{GNm} / 1.99$ \\
\hline
\end{tabular}

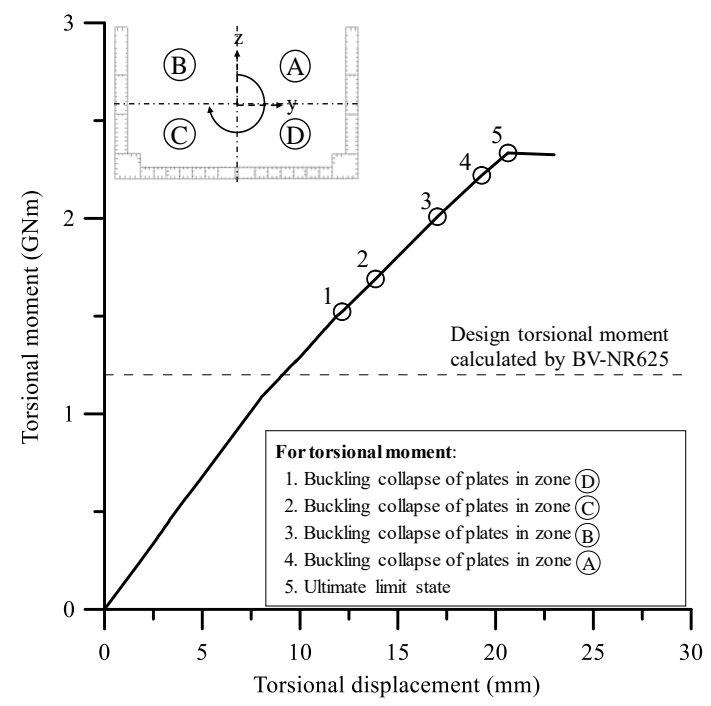

Figure 14. Progressive collapse behavior and failure events of the 9,300 TEU containership hull under a pure torsional moment. 
Table 4. Safety margin of the 9,300 TEU containership hull under pure torsional moment.

\begin{tabular}{|l|l|l|}
\hline Design load & $\begin{array}{l}\text { Ultimate strength / } \\
\text { Safety margin }\end{array}$ & $\begin{array}{l}\text { First failure moment / } \\
\text { Safety margin }\end{array}$ \\
\hline $1.20 \mathrm{GNm}$ & $2.33 \mathrm{GNm} / 1.94$ & $1.52 \mathrm{GNm} / 1.27$ \\
\hline
\end{tabular}

\subsubsection{Under pure torsional moment}

The progressive collapse behavior of the hull structures under a pure torsional moment is shown in Figure 14. It is found that the hull structure under pure torsion reaches the ultimate limit state, $M_{T u}$ at $2.33 \mathrm{GNm}$ with collapse of the deck panels. The first failure mode of the hull is the buckling collapse of zone D at $1.52 \mathrm{GNm}$ as shown in Figure 14. Table 4 indicates the safety margin of the 9,300 TEU containership hull under pure torsional moment. The design value of the total torsional moment at the mid-ship section in the full load condition is $1.20 \mathrm{GNm}$, as determined from the BV-NR625 standard (BV 2017). The safety margin of the hull in hogging condition is $2.33 / 1.20=1.94$ for the ultimate strength, but it is $1.52 / 1.20=$ 1.27 for the first failure event.

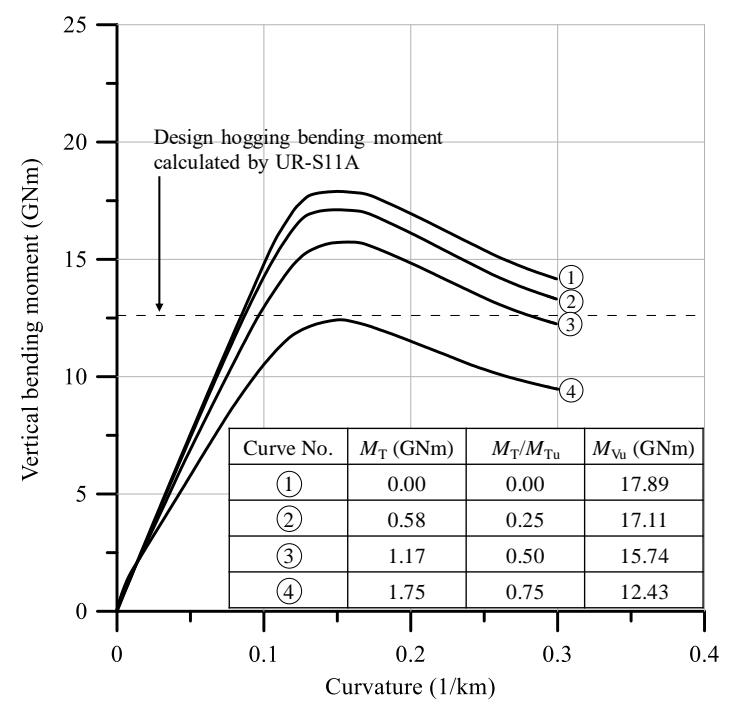

Figure 15. Progressive collapse behavior of the 9,300 TEU containership hull under combined hogging bending and torsional moments. 


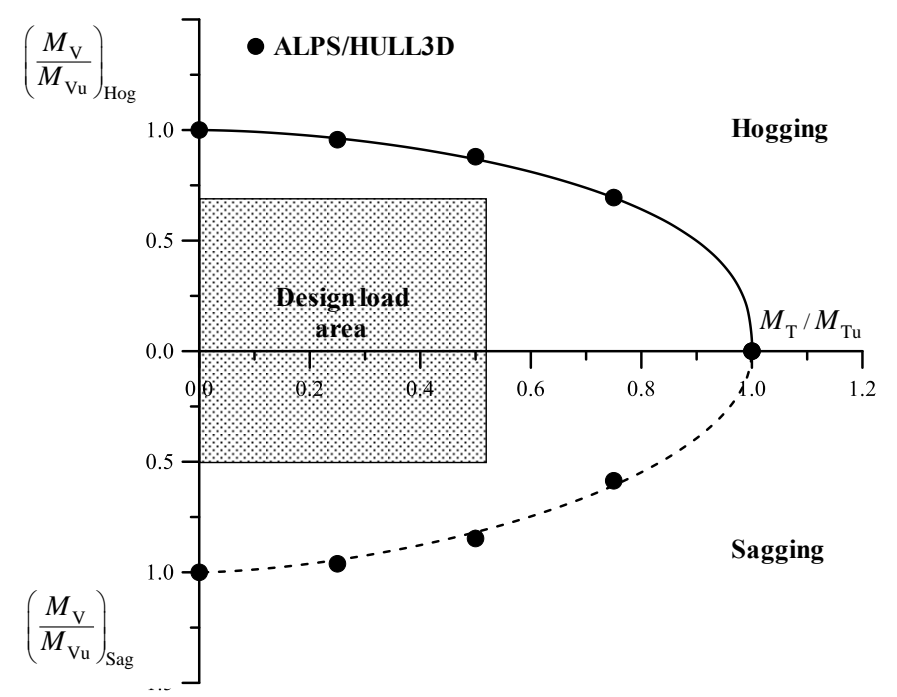

Figure 16. Ultimate strength interaction between vertical bending and torsional moments of the 9,300 TEU containership hull.

\subsubsection{Under combined vertical bending and pure torsional moments}

Figure 15 presents the effect of torsional moments on the progressive collapse behavior of the 9,300 TEU containership hull under a hogging bending moment. It is obvious that the ultimate bending moment is decreased as the torsional moment increases. Figure 16 shows the ultimate strength interaction relationship between vertical bending and torsional moments. Compared with the design load area in Figure 16, the 9,300 TEU containership hull is safe under the design values of combined vertical bending and torsional moments. The resulting interaction equations are given by

$$
\begin{gathered}
\left(\frac{M_{\mathrm{V}}}{M_{\mathrm{Vu}}}\right)_{\mathrm{Hog}}^{1.7}+\left(\frac{M_{\mathrm{T}}}{M_{\mathrm{Tu}}}\right)^{2.6}=1 \text { for hogging } \\
\left(\frac{M_{\mathrm{V}}}{M_{\mathrm{Vu}}}\right)_{\mathrm{Sag}}^{1.6}+\left(\frac{M_{\mathrm{T}}}{M_{\mathrm{Tu}}}\right)^{2.0}=1 \text { for sagging }
\end{gathered}
$$

where $M_{V u}$ is the ultimate vertical bending moment, $M_{T u}$ is the ultimate torsional moment, $M_{V}$ is the applied vertical bending moment, and $M_{T}$ is the applied torsional moment.

\subsection{As-built 13,000 TEU containership}

\subsubsection{Under pure vertical bending moment}

Figure 17 presents the ALPS/HULL3D model for the 13,000 TEU containership hull using 1,756 ISFEM plate elements. Figure 18 shows the progressive collapse behavior of the hull structure under a pure vertical bending moment in hogging or sagging. The 
first failure mode of the hull by local yielding occurs at the deck panels in hogging at a vertical bending moment of $20.17 \mathrm{GNm}$, and the hull reaches the ultimate limit state, $M_{V u, H o g}$ at a vertical bending moment of $22.71 \mathrm{GNm}$ after the buckling collapse of the outer bottom panels. In sagging, buckling collapse first occurs on the deck panels at a vertical bending moment of $19.04 \mathrm{GNm}$, and the ultimate limit state, $M_{V u, S a g}$ is reached at a vertical bending moment of $20.48 \mathrm{GNm}$, even before the bottom panels yield.

In general, the dominant vertical bending moments develop in hogging for containerships in full load condition, and thus sagging may not be of concern for containerships. Table 5 indicates the safety margin of the 13,000 TEU containership hull under vertical bending moments. The design value of the total hogging bending moment in full load condition is $16.62 \mathrm{GNm}$, as determined from the IACS UR-S11A standard (IACS 2015). The safety margin of the hull under hogging is $22.71 / 16.62=$ 1.37 for the ultimate strength, but it is $20.17 / 16.62=1.21$ for the first failure event.

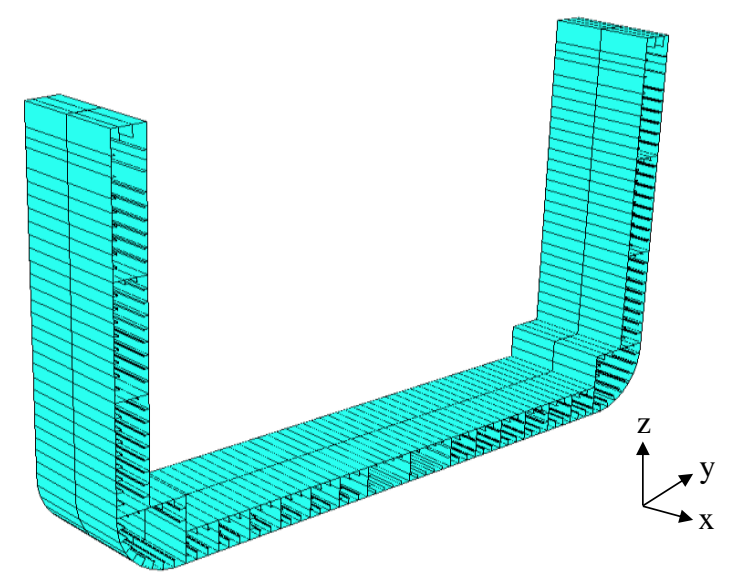

Figure 17. ALPS/HULL3D model for the 13,000 TEU containership hull using 1,756 ISFEM plate elements.



Figure 18. Progressive collapse behavior and failure events of the 13,000 TEU containership hull under pure vertical bending moments. 
Table 5. Safety margin of the 13,000 TEU containership hull under pure vertical bending moments.

\begin{tabular}{|l|l|l|l|}
\hline $\begin{array}{l}\text { Loading } \\
\text { condition }\end{array}$ & $\begin{array}{l}\text { Design } \\
\text { load }\end{array}$ & $\begin{array}{l}\text { Ultimate strength } \\
\text { Safety margin }\end{array}$ & $\begin{array}{l}\text { First failure moment / } \\
\text { Safety margin }\end{array}$ \\
\hline Hogging & $\begin{array}{l}16.62 \\
\text { GNm }\end{array}$ & $22.71 \mathrm{GNm} / 1.37$ & $20.17 \mathrm{GNm} / 1.21$ \\
\hline Sagging & $\begin{array}{l}10.11 \\
\text { GNm }\end{array}$ & $20.48 \mathrm{GNm} / 2.03$ & $19.04 \mathrm{GNm} / 1.88$ \\
\hline
\end{tabular}

\subsubsection{Under pure torsional moment}

The progressive collapse behavior of the hull structures under a pure torsional moment is shown in Figure 19. It is found that the hull structure under pure torsion reaches the ultimate limit state, $M_{T u}$ at a torsional moment of $4.40 \mathrm{GNm}$ with the collapse of the deck panels. Figure 20 presents the distribution of shear stresses over the hull cross-section at the ultimate limit state under pure torsional moment. The first failure mode of the hull is buckling collapse of zone D at $2.41 \mathrm{GNm}$ as shown in Figure 19.

Table 6 presents the safety margin of the 13,000 TEU containership hull under a pure torsional moment. The design value of the total torsional moment at the mid-ship section under full load is $1.76 \mathrm{GNm}$, as determined from the BV-NR625 standard (BV 2017). The safety margin of the hull is $4.40 / 1.76=2.50$ for the ultimate strength, but it is $2.41 / 1.76=1.37$ for the first failure event.



Figure 19. Progressive collapse behavior and failure events of the $13,000 \mathrm{TEU}$ containership hull under a pure torsional moment. 


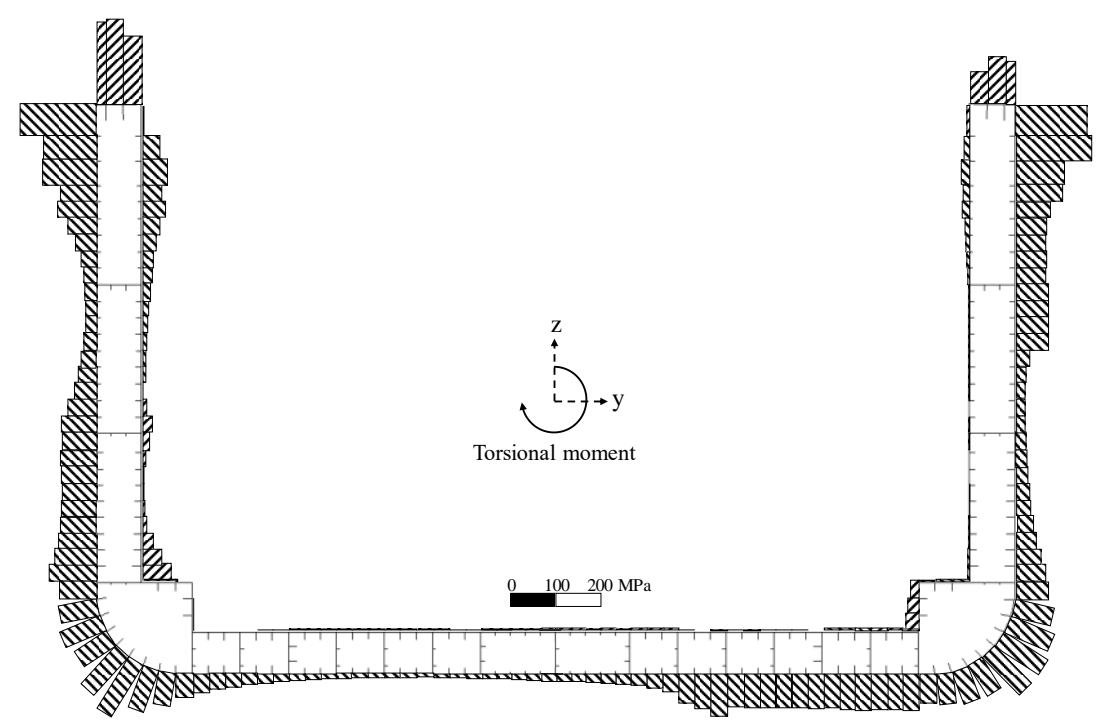

Figure 20. Distribution of shear stresses over the hull cross section at the ultimate limit state of the 13,000 TEU containership hull under a pure torsional moment.

Table 6. Safety margin of the as-built 13,000 TEU containership hull under a pure torsional moment.

\begin{tabular}{|l|l|l|}
\hline Design load & $\begin{array}{l}\text { Ultimate strength / } \\
\text { Safety margin }\end{array}$ & $\begin{array}{l}\text { First failure moment / } \\
\text { Safety margin }\end{array}$ \\
\hline $1.76 \mathrm{GNm}$ & $4.40 \mathrm{GNm} / 2.50$ & $2.41 \mathrm{GNm} / 1.37$ \\
\hline
\end{tabular}

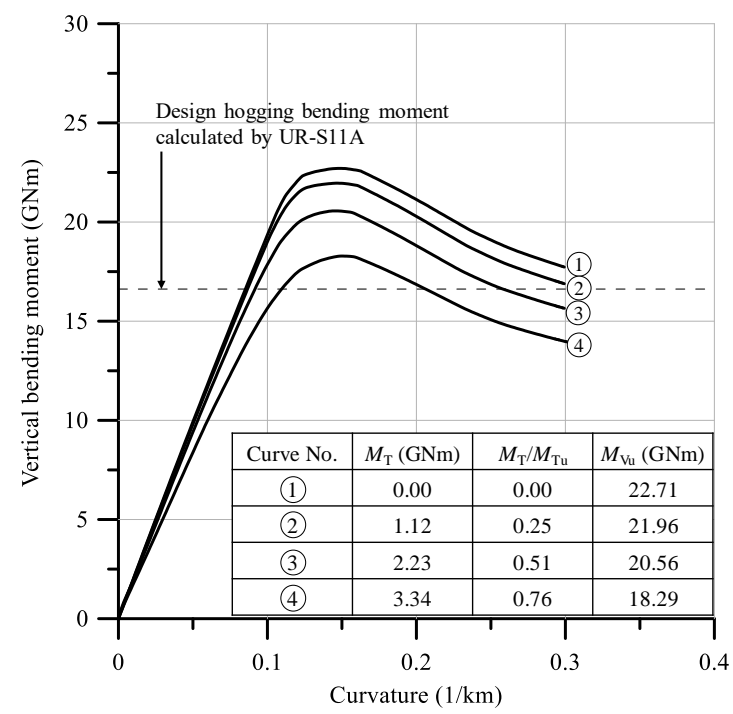

Figure 21. Progressive collapse behavior of the 13,000 TEU containership hull under combined hogging bending and torsional moments. 


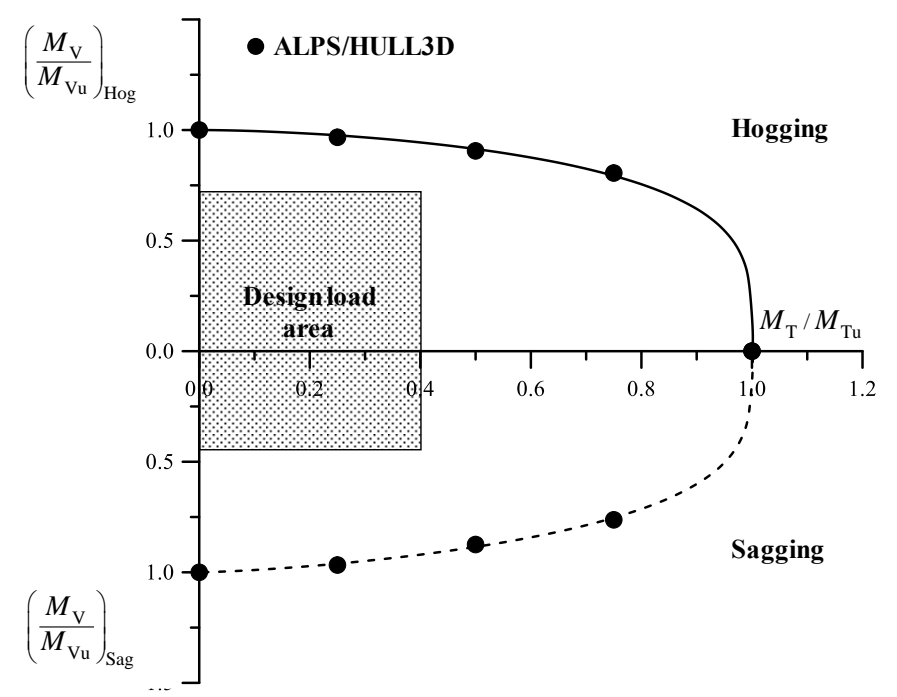

Figure 22. Ultimate strength interaction between vertical bending and torsional moments of the 13,000 TEU containership hull.

\subsubsection{Under combined vertical bending and torsional moments}

Figure 21 presents the effect of torsional moments on the progressive collapse behavior of the 13,000 TEU containership hull under a hogging bending moment. Similar to the 9,300 TEU containership hull, the ultimate bending moment is decreased as the torsional moment increases. Figure 22 shows the ultimate strength interaction relationship between the vertical bending and torsional moments. Compared with the design load area shown in Figure 22, the 13,000 TEU containership hull is safe under the design value of combined vertical bending and torsional moments. The resulting interaction equations are given by

$$
\begin{aligned}
& \left(\frac{M_{\mathrm{V}}}{M_{\mathrm{Vu}}}\right)_{\mathrm{Hog}}^{1.7}+\left(\frac{M_{\mathrm{T}}}{M_{\mathrm{Tu}}}\right)^{4.1}=1 \text { for hogging } \\
& \left(\frac{M_{\mathrm{V}}}{M_{\mathrm{Vu}}}\right)_{\mathrm{Sag}}^{1.6}+\left(\frac{M_{\mathrm{T}}}{M_{\mathrm{Tu}}}\right)^{3.5}=1 \text { for sagging }
\end{aligned}
$$

\subsection{As-built 22,000 TEU containership}

\subsubsection{Under pure vertical bending moment}

Figure 23 presents the ALPS/HULL3D model for the 22,000 TEU containership hull using 1,833 ISFEM plate elements. Figure 24 shows the progressive collapse behavior of the hull structure under pure vertical bending moments in hogging or sagging. It is found that the first failure mode of the hull by yielding occurs at the deck panels in hogging at a vertical bending moment of $32.85 \mathrm{GNm}$, and the hull reaches the ultimate limit state, $M_{V u, H o g}$ at a vertical bending moment of $36.78 \mathrm{GNm}$ after the buckling collapse of the outer bottom panels. In sagging, buckling collapse first 
occurs on the deck panels at a vertical bending moment of $29.66 \mathrm{GNm}$, and the ultimate limit state, $M_{V u, S a g}$ is reached at a vertical bending moment of $34.50 \mathrm{GNm}$ with yielding of the bottom structures.

Table 7 presents the safety margin of the 22,000 TEU containership hull under vertical bending moments. The design value of the total hogging bending moment under full load is $22.42 \mathrm{GNm}$, as determined from the IACS UR-S11A (IACS 2015). The safety margin of the hull in hogging is $36.78 / 22.42=1.64$ for the ultimate strength, but it is $32.85 / 22.42=1.47$ for the first failure event.

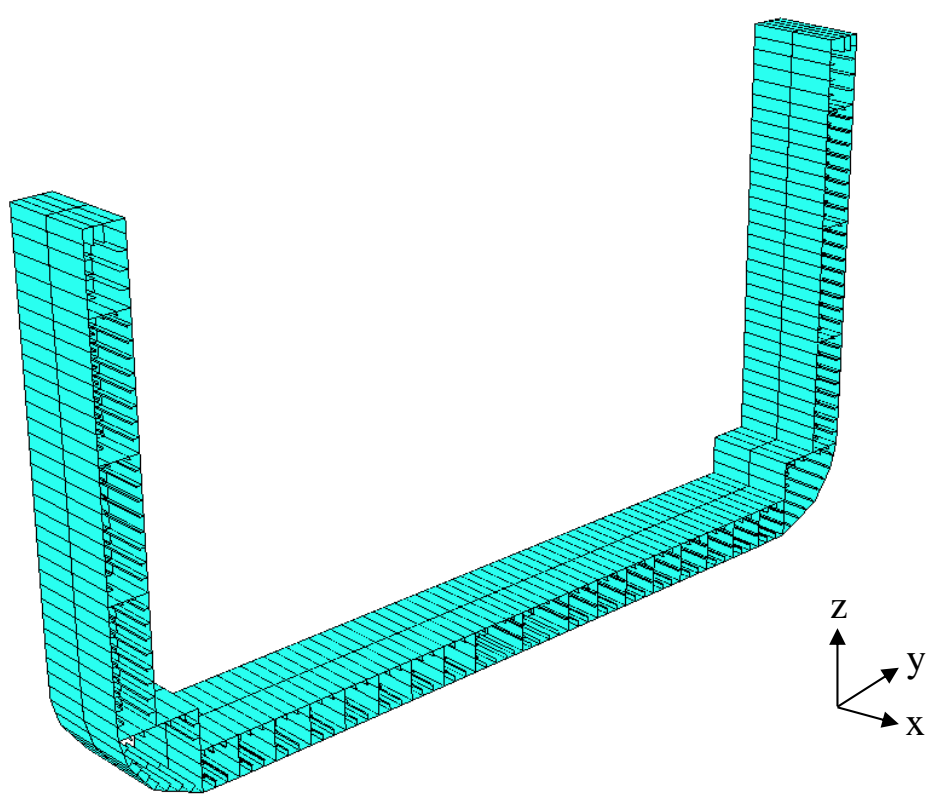

Figure 23. ALPS/HULL3D model for the 22,000 TEU containership hull using 1,756 ISFEM plate elements.



Figure 24. Progressive collapse behavior and failure events of the 22,000 TEU containership hull under a pure vertical bending moment. 
Table 7. Safety margin of the 22,000 TEU containership hull under a pure vertical bending moment.

\begin{tabular}{|l|l|l|l|}
\hline $\begin{array}{l}\text { Loading } \\
\text { condition }\end{array}$ & $\begin{array}{l}\text { Design } \\
\text { load }\end{array}$ & $\begin{array}{l}\text { Ultimate strength / } \\
\text { Safety margin }\end{array}$ & $\begin{array}{l}\text { First failure moment / } \\
\text { Safety margin }\end{array}$ \\
\hline Hogging & $\begin{array}{l}22.42 \\
\text { GNm }\end{array}$ & $36.78 \mathrm{GNm} / 1.64$ & $32.85 \mathrm{GNm} / 1.47$ \\
\hline Sagging & $\begin{array}{l}13.82 \\
\text { GNm }\end{array}$ & $34.50 \mathrm{GNm} / 2.50$ & $29.66 \mathrm{GNm} / 2.14$ \\
\hline
\end{tabular}

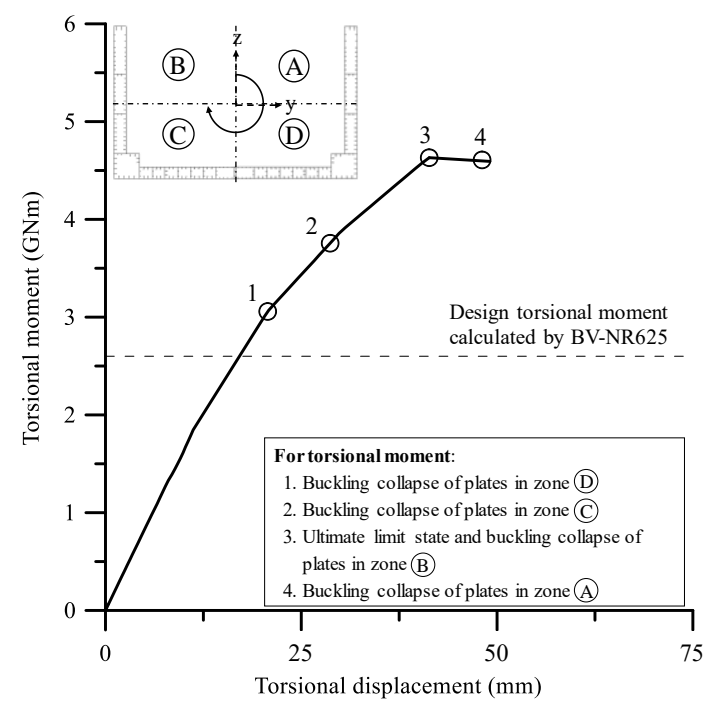

Figure 25. Progressive collapse behavior and failure events of the 22,000 TEU containership hull under a pure torsional moment.

\subsubsection{Under pure torsional moment}

The progressive collapse behavior of the hull structures under a pure torsional moment is shown in Figure 25. It is found that the hull structure under pure torsion reaches the ultimate limit state, $M_{T u}$ at a torsional moment of $4.63 \mathrm{GNm}$ with collapse of the deck panels. The first failure mode of the hull is the buckling collapse of zone D at a torsional moment of $3.06 \mathrm{GNm}$ as shown in Figure 22.

Table 8 indicates the safety margin of the 22,000 TEU containership hull under a pure torsional moment. The design value of the total torsional moment at the mid-ship section under full load is $2.60 \mathrm{GNm}$, as determined from the BV-NR625 (BV 2017). The safety margin of the hull is $4.63 / 2.60=1.78$ for the ultimate strength, but it is $3.06 / 2.60=1.18$ for the first failure event.

Table 8. Safety margin of the 22,000 TEU containership hull under a pure torsional moment.

\begin{tabular}{|l|l|l|}
\hline Design load & $\begin{array}{l}\text { Ultimate strength / Safety } \\
\text { margin }\end{array}$ & $\begin{array}{l}\text { First failure moment / } \\
\text { Safety margin }\end{array}$ \\
\hline $2.60 \mathrm{GNm}$ & $4.63 \mathrm{GNm} / 1.78$ & $3.06 \mathrm{GNm} / 1.18$ \\
\hline
\end{tabular}




\subsubsection{Under combined vertical bending and torsional moments}

Figure 26 presents the effect of torsional moments on the progressive collapse behavior of the 22,000 TEU containership hull under a hogging bending moment. Similar to both of the 9,300 TEU and 13,000 TEU containership hulls, the ultimate bending moment is decreased as the torsional moment increases. Figure 27 shows the ultimate strength interaction relationship between the vertical bending and torsional moments. Compared with the design load area shown in Figure 27, the 22,000 TEU containership hull is safe under the design value of combined vertical bending and torsional moments. The resulting interaction equations for the as-built 22,000 TEU containership hull are given by

$$
\begin{gathered}
\left(\frac{M_{\mathrm{V}}}{M_{\mathrm{Vu}}}\right)_{\mathrm{Hog}}^{1.7}+\left(\frac{M_{\mathrm{T}}}{M_{\mathrm{Tu}}}\right)^{7.3}=1 \text { for hogging } \\
\left(\frac{M_{\mathrm{V}}}{M_{\mathrm{Vu}}}\right)_{\mathrm{Sag}}^{1.6}+\left(\frac{M_{\mathrm{T}}}{M_{\mathrm{Tu}}}\right)^{7.5}=1 \text { for sagging }
\end{gathered}
$$



Figure 26. Progressive collapse behavior of the 22,000 TEU containership hull under combined hogging bending and torsional moments. 




Figure 27. Ultimate strength interaction between vertical bending and torsional moments of the 22,000 TEU containership hull.

\section{Discussion and design recommendations}

The ultimate strength characteristics of the three as-built containership hulls have been investigated under combined vertical bending and torsional moments, together with pure vertical bending or torsion. Figure 28 presents the safety margin trend based on the ultimate strength or first failure event with varying the ship size. The safety margin for the ultimate hull girder strength under pure vertical bending in hogging is in the range of $1.3-1.7$ while it is in the range of $1.7-2.5$ for pure torsional moment. It is however observed that the trend of the safety margin for the ultimate strength is not obvious with varying the ship size. This may be due to the fact that the structural design of ultra-large containerships involves various complex issues associated with wave-induced hull girder load requirements (Paik et al. 2019), hull materials, and structural scantlings, among others (Hughes and Paik 2013).

The full plastic bending moment, $M_{P}$ is an important indicator of structural scantlings in box girders or ship hull structures under bending moments where local buckling is not considered but local members fully yield. The value of $M_{P}$ for a ship hull can be calculated using simple beam theory as a box girder under vertical bending moment (Paik 2018), and the computed values of $M_{P}$ for the three containerships are provided in Table 9.

Figure 29 summarizes the ultimate strength computations for the three containership hulls normalized by the full plastic bending moment. It is interesting to say that the ultimate hull girder strength normalized by $M_{P}$ is smaller for larger ships except when the ship hull is under very large torsional moments. This may be due to the fact that the ultra-large containership hulls built in recent years have used much higher tensile steels, e.g., DH36, AH40, or EH40, together with very thick 
plating on decks (without causing local buckling), and subsequently the full plastic bending moment has increased significantly.



(a) Under a vertical bending moment

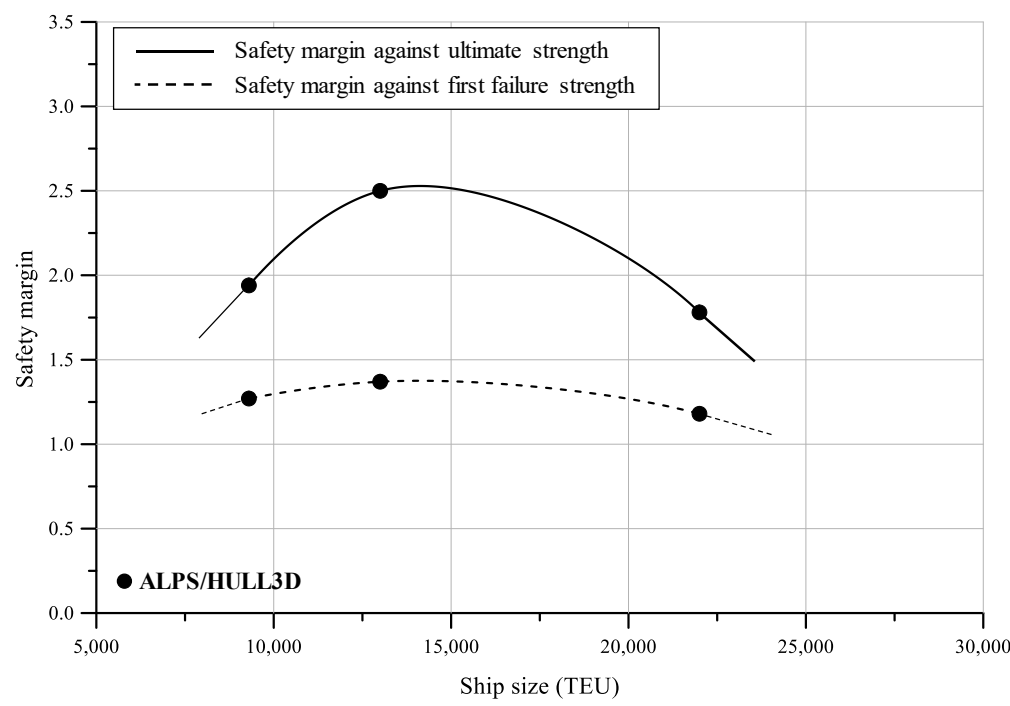

(b) Under a torsional moment

Figure 28. Safety margin trend for containership hulls based on the ultimate strength or first failure with varying the ship size.

Table 9. Summary of ultimate strength computations for the three as-built containership hulls.

\begin{tabular}{|c|c|c|c|c|c|c|}
\hline \multirow{2}{*}{ Ship size } & $M_{P}$ & $M_{T} / M_{T u}$ & \multicolumn{2}{|c|}{ Hogging } & \multicolumn{2}{c|}{ Sagging } \\
\cline { 4 - 7 } & & $M_{V u, H o g}$ & $M_{V u, H o g} / M_{P}$ & $M_{V u, S a g}$ & $M_{V u, S a g} / M_{P}$ \\
\hline $\begin{array}{c}9,300 \\
\text { TEU }\end{array}$ & 18.42 & 0.00 & $17.89 \mathrm{GNm}$ & 0.971 & $\begin{array}{l}15.40 \\
\mathrm{GNm}\end{array}$ & 0.836 \\
\cline { 3 - 7 } & $\mathrm{GNm}$ & 0.25 & $17.11 \mathrm{GNm}$ & 0.929 & $\begin{array}{l}14.81 \\
\mathrm{GNm}\end{array}$ & 0.804 \\
\hline
\end{tabular}




\begin{tabular}{|c|c|c|c|c|c|c|}
\hline & & 0.50 & $15.74 \mathrm{GNm}$ & 0.855 & $\begin{array}{l}13.05 \\
\text { GNm }\end{array}$ & 0.708 \\
\hline & & 0.75 & $12.43 \mathrm{GNm}$ & 0.675 & $9.03 \mathrm{GNm}$ & 0.490 \\
\hline \multirow{4}{*}{$\begin{array}{c}13,000 \\
\text { TEU }\end{array}$} & \multirow{4}{*}{$\begin{array}{l}24.75 \\
\text { GNm }\end{array}$} & 0.00 & $22.71 \mathrm{GNm}$ & 0.918 & $\begin{array}{l}20.48 \\
\text { GNm }\end{array}$ & 0.827 \\
\hline & & 0.25 & $21.96 \mathrm{GNm}$ & 0.887 & $\begin{array}{l}19.81 \\
\text { GNm }\end{array}$ & 0.800 \\
\hline & & 0.50 & $20.56 \mathrm{GNm}$ & 0.831 & $\begin{array}{l}17.91 \\
\text { GNm }\end{array}$ & 0.724 \\
\hline & & 0.75 & 18.29 GNm & 0.739 & $\begin{array}{l}15.62 \\
\text { GNm }\end{array}$ & 0.631 \\
\hline \multirow{4}{*}{$\begin{array}{c}22,000 \\
\text { TEU }\end{array}$} & \multirow{4}{*}{$\begin{array}{l}42.58 \\
\text { GNm }\end{array}$} & 0.00 & $36.78 \mathrm{GNm}$ & 0.864 & $\begin{array}{l}34.50 \\
\text { GNm }\end{array}$ & 0.810 \\
\hline & & 0.25 & 36.10 GNm & 0.848 & $\begin{array}{l}33.97 \\
\text { GNm }\end{array}$ & 0.798 \\
\hline & & 0.50 & $34.97 \mathrm{GNm}$ & 0.821 & $\begin{array}{l}32.71 \\
\text { GNm }\end{array}$ & 0.768 \\
\hline & & 0.75 & $32.29 \mathrm{GNm}$ & 0.758 & $\begin{array}{l}30.20 \\
\text { GNm }\end{array}$ & 0.709 \\
\hline
\end{tabular}

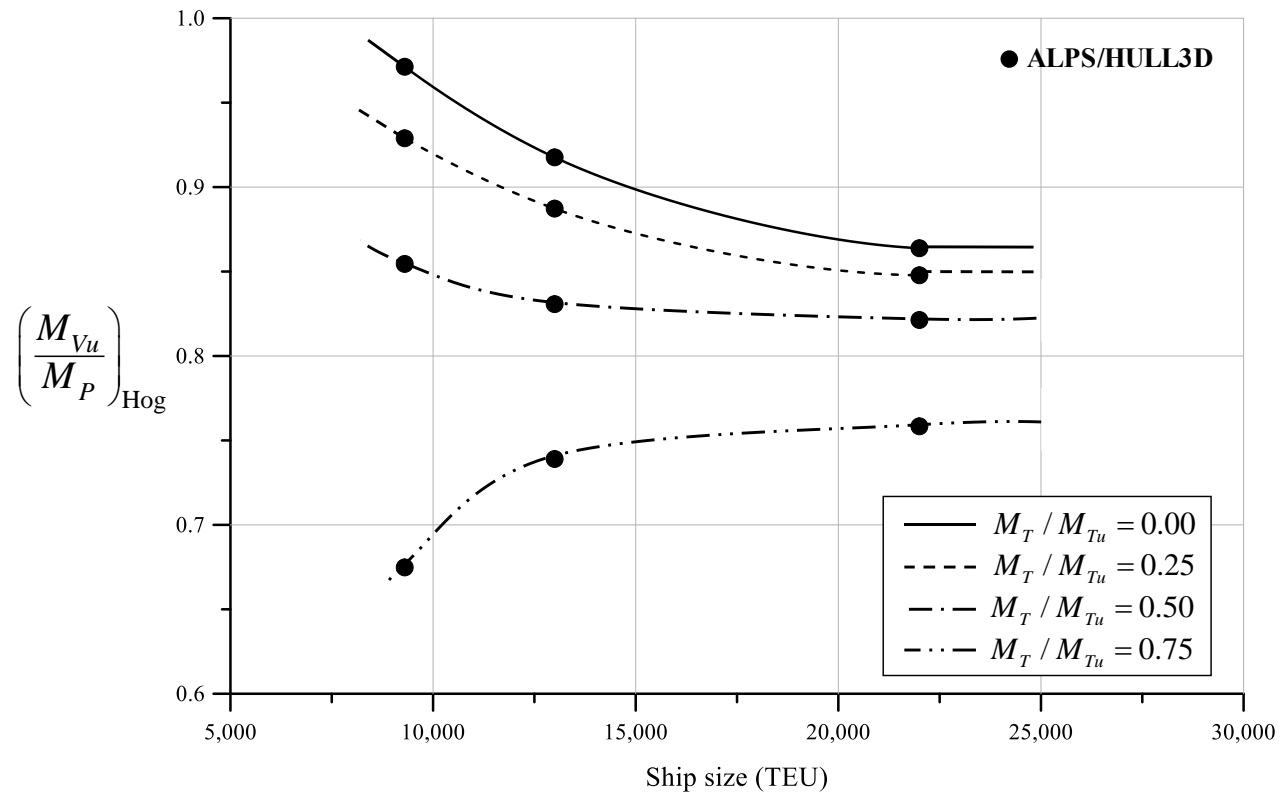

(a) Under combined hogging vertical bending and torsion 


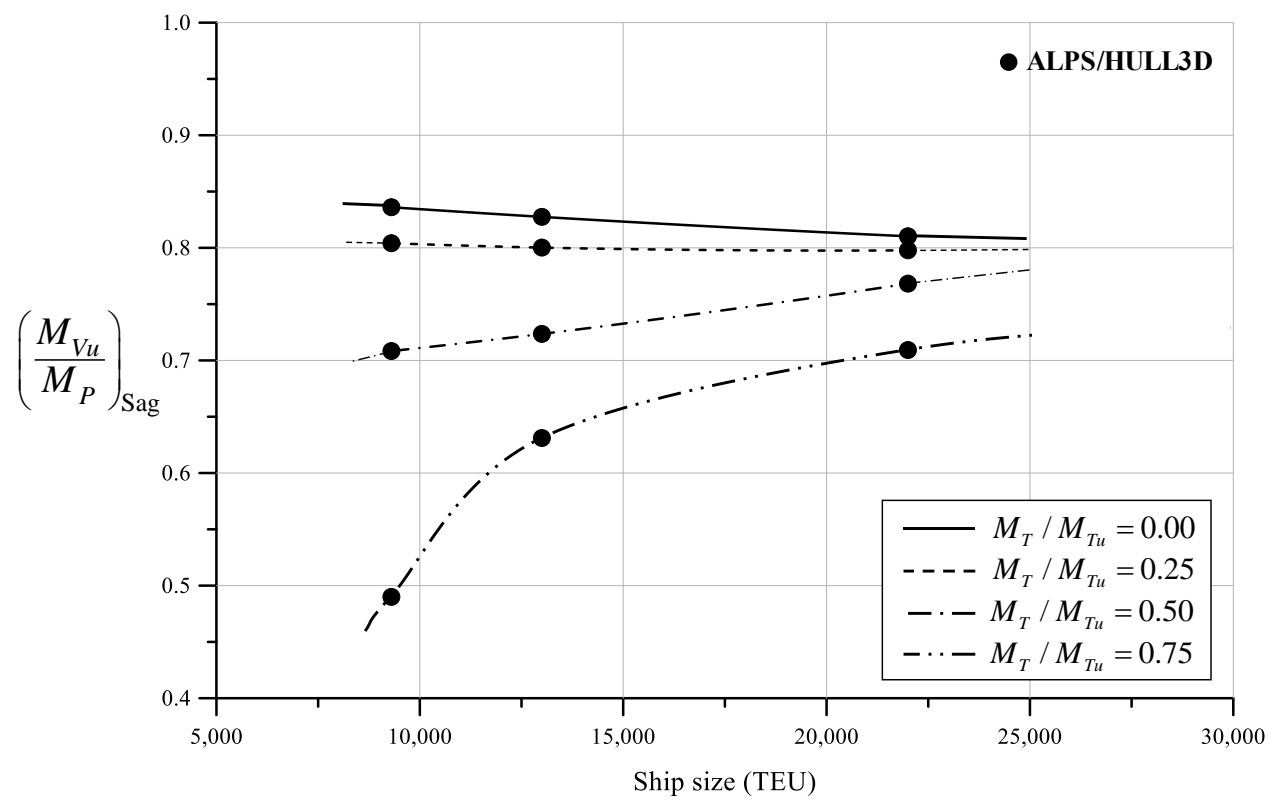

(b) Under combined sagging vertical bending and torsion

Figure 29. Change of the ultimate hull girder strength normalized by the full plastic bending moment with varying the ship size.

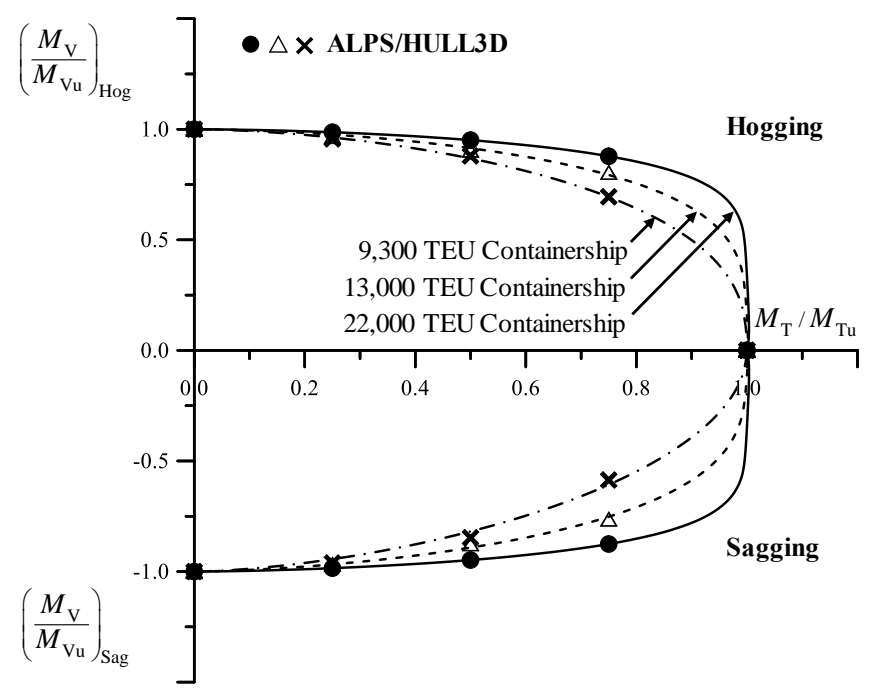

Figure 30. Ultimate hull girder strength interaction relationships between vertical bending and torsion for different sizes of containership.

Figure 30 presents the ultimate hull girder strength interaction diagrams for all the three ships under combined vertical bending and torsional moments. The interacting curve of the ultimate hull girder strength becomes more stacked or convex in large torsional moments as the ship size increases. This result is somewhat different from past findings where the ultimate hull girder strength interactive curve between vertical bending and torsional moments is almost similar regardless of the ship size as far as relatively small ships are considered (Paik et al. 2001). This may be due to the fact the recent ultra-large containerships have changed structural arrangements together with scantlings and material properties. Also, this demonstrates the importance of studying 
with ultra-large ships built in recent years as the ultimate strength characteristics of recent ship structures can differ from those of past ship structures.

It is found that the effect of torsional moments on the ultimate vertical bending moments is more significant in smaller containerships. In this regard, it is recommended that the non-dimensionalized ultimate vertical bending moment capacity (i.e., the ratio of the ultimate vertical bending moment under combined bending and torsion to that under pure vertical bending moment) be enhanced up to the level of ultra-large containerships carrying more than 20,000 TEU.

Figure 31 presents the first failure (by local buckling or yielding) or ultimate strength-based interaction relationships. The design load area is determined from the design rules of classification societies. It is observed that the three as-built containerships are safe, with tolerances against the first failure event and the ultimate limit state (ultimate strength). However, the two containerships carrying 9,300 TEU and 13,000 TEU could potentially be at risk of first failure when both vertical bending and torsional moments are equally predominant. Also, it is seen that the largest containership, i.e., carrying 22,000 TEU may be vulnerable to first failure when the torsional moments are significant as far as the design loads determined from the classification society rules are applied.

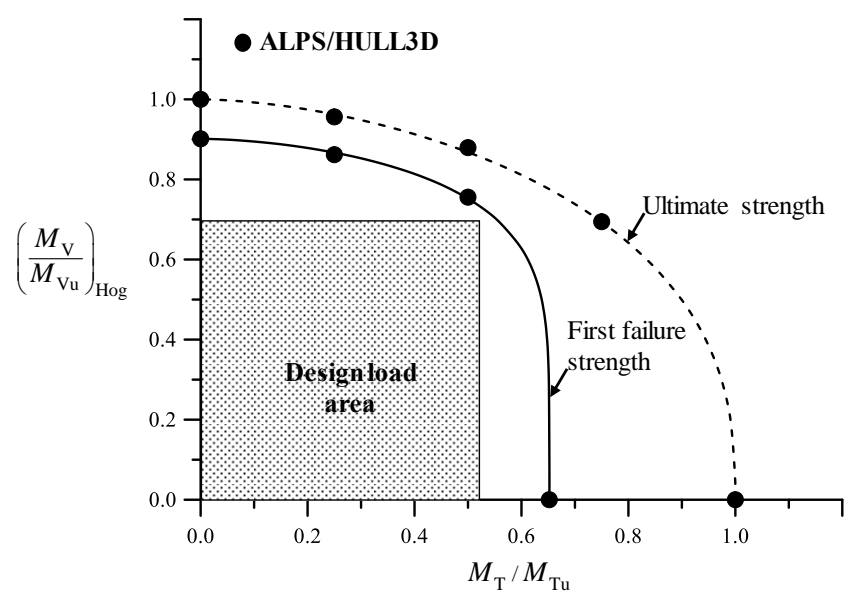

(a) As-built 9,300 TEU containership

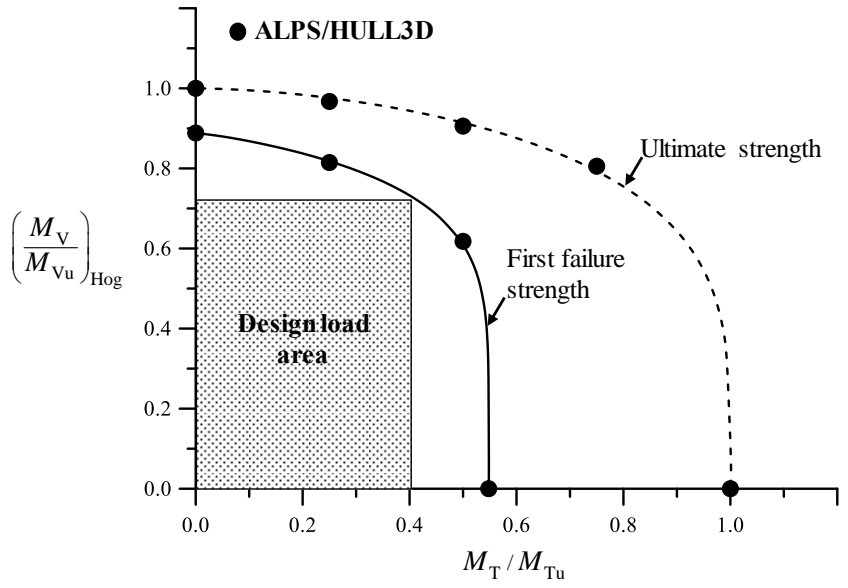

(b) As-built 13,000 TEU containership 


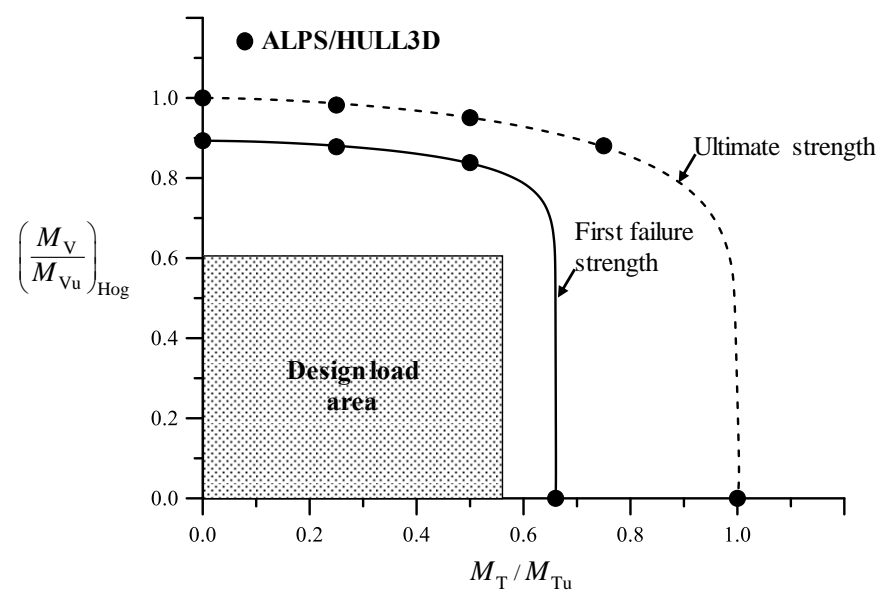

(c) As-built 22,000 TEU containership

Figure 31. First failure moment interaction relationships between vertical bending and torsional moments of the containership hulls.

This paper focuses on breakage of hull girder amidship under combined vertical bending and torsion. The effect of horizontal bending on the ultimate hull girder strength is another important subject to study. The length of parallel body of ultra-large crude oil carriers is as much as $0.65 \mathrm{~L}$, while that of ultra-large containerships is $0.2 \mathrm{~L}$. Figure 32 shows design load distribution curves of vertical bending moments (IACS 2015) and torsional moments (BV 2017) along ship length. It is found that the largest load locations for vertical bending moments and torsional moments are not identical. In this regard, it is recommended that the ship structural safety against hull girder breakage shall be checked out not only amidship but also at suspicious locations where either torsional moments or bending moments are maximized.

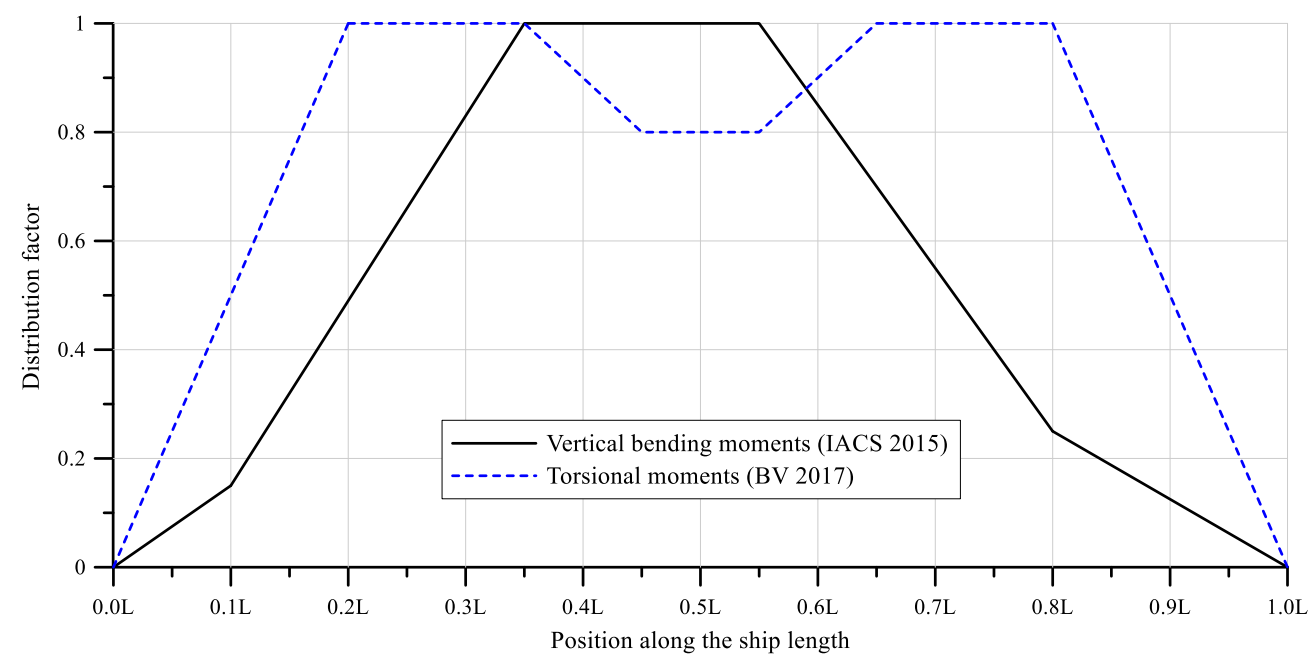

Figure 32. Distribution curves of vertical bending moments and torsional moments along ship length. 


\section{Concluding remarks}

The aim of the present study has been to investigate the ultimate strength characteristics of as-built ultra-large containership hulls under combined vertical bending and torsional moments. For this purpose, three as-built containerships carrying 9,300 TEU, 13,000 TEU, and 22,000 TEU were studied. The ISFEM was employed to compute the progressive collapse behavior of hull structures until and after the ultimate strength was reached. Based on the present study, the following conclusions can be drawn:

(1) The size of containerships has increased substantially in recent years. Containerships have doubled in size over the last decade. Ultra-large containerships carrying 22,000 TEU have appeared, and those carrying 25,000 TEU may appear in the near future. However, many technical challenges need to be resolved in terms of structural safety and integrity, among other factors, as the containership sizes increase.

(2) Because containership hulls have large deck openings, they may be vulnerable to structural failure due to torsional moments which are combined with vertical bending. It is observed that the effect of torsional moments on the ultimate hull girder bending strength becomes more significant with increase in the containership size.

(3) The ultimate hull girder strength characteristics of small-sized containerships differ from those of ultra-large containerships. Furthermore, their characteristics for ships built in recent years are different from those for past ships. The safety margin against the ultimate hull girder strength under pure vertical bending in hogging is in the range of $1.3-1.7$ while it is in the range of $1.7-2.5$ for pure torsional moment. However, the trend of the safety margin is not obvious with varying the containership size. This may be due to the structural design requirements of ultra-large containerships associated with wave-induced hull girder loads, hull materials, and structural scantlings, among others.

(4) The hull girder strength interaction relationships of as-built ultra-large containerships under combined vertical bending and torsional moments are studied based on the ultimate strength or first failure (by local buckling or yielding) by developing their closed-form expressions. The characteristics of ultimate hull girder strength interaction relationships between vertical bending and torsional moments differ depending on the size of containership. The strength interaction relationships between them are more sensitive for smaller containerships. Also, it is observed that the 22,000 TEU containership may be at risk when torsional moments are predominant, and the two containerships carrying 9,300 TEU and 13,000 TEU may be vulnerable to first failure when vertical bending and torsional moments are equally dominant.

(5) It is recommended that the non-dimensionalized ultimate vertical bending moment (i.e., the ratio of the ultimate vertical bending moment under combined bending and torsion to that under pure vertical bending) for smaller 
containerships be enhanced further up to the level of ultra-large containerships carrying more than 20,000 TEU.

(6) Also, the ship structural safety against hull girder collapse under combined bending and torsion be checked out not only amidship but also at suspicious locations where either torsional moments or vertical bending moments are maximized.

It is hoped that the works and insights obtained from the present study will be useful for the robust structural design of ultra-large containership hull structures.

\section{Acknowledgments}

This work was supported by a 2-Year Research Grant of Pusan National University.

\section{References}

Alfred Mohammed E, Benson SD, Hirdaris SE, Dow RS. 2016. Design safety margin of a 10,000 TEU container ship through ultimate hull girder load combination analysis. Marine Structures. 46: 78-101.

ALPS/HULL. 2018. A computer program for the progressive hull girder collapse analysis of ships. MAESTRO Marine LLC, Greenboro, MD, USA (www.maestromarine.com).

ALPS/HULL3D. 2019. A computer program for the progressive hull girder collapse analysis of ships. MAESTRO Marine LLC, Greenboro, MD, USA (www.maestromarine.com).

ALPS/ULSAP. 2019. A computer program for the ultimate strength analysis of plates and stiffened panels. MAESTRO Marine LLC, Greenboro, MD, USA (www.maestromarine.com).

BV. 2017. Structural rules for container ships (NR 625). Bureau Veritas, Paris, France.

Caldwell JB. 1965. Ultimate longitudinal strength. Transactions of the Royal Institution of Naval Architects. 107: 411-418.

ClassNK. 2014. Investigation report on the structural safety of a large containership. Nippon Kaiji Kyokai, Tokyo, Japan.

Dow RS. 1991. Testing and analysis of 1/3-scale welded steel frigate model. Proceedings of the International Conference on Advances in Marine Structures, Dunfermline, Scotland, 749-773.

Hughes OF, Paik JK. 2013. Ship structural analysis and design. Alexandria, USA: The Society of Naval Architects and Marine Engineers.

IACS. 2015. Longitudinal strength standard for container ships (UR-S11A). International Association of Classification Societies, London, UK.

Kim DK, Park DH, Kim HB, Kim BJ, Seo JK, Paik JK. 2013. Lateral pressure effects on the progressive hull collapse behavior of a Suezmax-class tanker under vertical bending moments. Ocean Engineering. 63: 112-121.

Mohammed EA, Benson SD, Hirdaris SE, Dow RS. 2016. Design safety margin of a 
10,000 TEU container ship through ultimate hull girder load combination analysis. Marine Structures. 46: 78-101.

Ostapenko A. 1981. Strength of ship hull girders under moment, shear and torque. Proceedings of Extreme Loads Response Symposium, SSC-SNAME, Arlington, VA, October.

Ostapenko A, Moore TR. 1982. Maximum strength of ship hulls subjected to moment, torque and shear. Report No. 479.5, Fritz Engineering Laboratory, Lehigh University, November.

Ostapenko A, Vaucher A. 1980. Ultimate strength of ship hull girders under moment, shear and torque. Report No. 453.6, Fritz Engineering Laboratory, Lehigh University, July.

Ostergaard C, Dogliani M, Guedes Soares C, Parmentier G, Pedersen PT. 1996. Measures of model uncertainty in the assessment of primary stresses in ship structures. Marine Structures. 9: 427-447.

Paik JK. 2015. What will be the maximum size of container vessels? South Korea: New Horizons, Hyundai Heavy Industries Co. Ltd; p.32-33.

Paik JK. 2018. Ultimate limit state analysis and design of plated structures, $2^{\text {nd }}$ Edition. Chichester, UK: John Wiley \& Sons.

Paik JK. 2019. Advanced structural safety studies: with extreme conditions and accidents. Singapore: Springer.

Paik JK, Kim BJ, Seo JK. 2008a. Method for ultimate limit state assessment of ships and ship-shaped offshore structures: Part I-unstiffened panels. Ocean Engineering. 35(2): 261-270.

Paik JK, Kim BJ, Seo JK. 2008b. Method for ultimate limit state assessment of ships and ship-shaped offshore structures: Part II stiffened panels. Ocean Engineering. 35(2): 271-280.

Paik JK, Kim BJ, Seo JK. 2008c. Method for ultimate limit state assessment of ships and ship-shaped offshore structures: Part III hull girders. Ocean Engineering. 35(2): 281-286.

Paik JK, Kim DK, Park DH, Kim HB, Mansour AE, Caldwell JB. 2012. Modified Paik-Mansour formula for ultimate strength calculations of ship hulls. Ships and Offshore Structures. 8(3-4): 245-260.

Paik JK, Mansour AE. 1995. A simple formulation for predicting the ultimate strength of ships. Journal of Marine Science and Technology. 1(1): 52-62.

Paik JK, Lee DH, Kim SJ, Thomas G, Ma M. 2019. A new method for determining the design values of wave-induced hull girder loads acting on ships. Ships and Offshore Structures. 14(Sup1): 63-90.

Paik JK, Thayamballi AK, Pedersen PT, Park YI. 2001. Ultimate strength of ship hulls under torsion. Ocean Engineering. 28: 1097-1133.

Paik JK, Thayamballi AK, Lee JM. 2004. Effect of initial deflection shape on the ultimate strength behavior of welded steel plates under biaxial compressive loads. Journal of Ship Research. 48(1): 45-60.

Pedersen PT. 1991. Beam theories for torsional-bending response of ship hulls. Journal of Ship Research. 35(3): 254-265. 
Rutherford SE, Caldwell JB. 1990. Ultimate longitudinal strength of ships: a case study. The Transactions of the Society of Naval Architects and Marine Engineers. 98: 441-471.

Schuler M. 2018. Photos: The worst containership disasters in recent history [Digital Image]. gCaptain, March 12, 2018. https://gcaptain.com/the-worst-containership-disasters-in-recent-history-in-photos/

Smith CS. 1997. Influence of local compressive failure on ultimate longitudinal strength of ship's hull. Proceedings of the International Symposium on Practical Design in Shipbuilding, Tokyo, 73-79.

Sun HH, Guedes Soares C. 2003. An experimental study of ultimate torsional strength of a ship-type hull girder with a large deck opening. Marine Structures. 16: 51-67.

Syrigou MS, Dow RS. 2018. Strength of steel and aluminium alloy ship plating under combined shear and compression/tension. Engineering Structures. 166: 128-141.

Tanaka Y, Ogawa H, Tatsumi A, Fujikubo M. 2015. Analysis method of ultimate hull girder strength under combined loads. Ships and Offshore Structures. 10: 587-598.

Teixeira AP, Ivanov LD, Guedes Soares C. 2013. Assessment of characteristic values of the ultimate strength of corroded steel plates with initial imperfections. Engineering Structures. 56: 517-527.

Ueda Y, Rashed SMH. 1974. An ultimate transverse strength analysis of ship structures. Journal of the Society of Naval Architects of Japan. 136: 309-324 (in Japanese).

Ueda Y, Rashed SMH. 1984. The idealized structural unit method and its application to deep girder structures. Computers \& Structures. 18(2): 277-293.

Ueda Y, Rashed SMH. 1991. Advances in the application of ISUM to marine structures. Proceedings of the $2^{\text {nd }}$ International Conference on Advances in Marine Structures, Dunfermline, Scotland, May, 628-649,

Ueda Y, Rashed SMH, Nakacho K, Sasaki H. 1983. Ultimate strength analysis of offshore structures -application of idealized structural unit method. Journal of the Kansai Society of Naval Architects of Japan. 190: 131-142 (in Japanese).

Ueda Y, Rashed SMH, Paik JK. 1984. Plate and stiffened panel units of the idealized structural unit method ( $1^{\text {st }}$ report) - under in-plane loading. Journal of the Society of Naval Architects of Japan. 156: 389-400 (in Japanese).

Ueda Y, Rashed SMH, Paik JK. 1986a. Plate and stiffened panel units of the idealized structural unit method $\left(2^{\text {nd }}\right.$ report $)$ - under in-plane and lateral loading considering initial deflection and residual stress. Journal of the Society of Naval Architects of Japan. 160: 321-339 (in Japanese).

Ueda Y, Rashed SMH, Paik JK, Masaoka K. 1986b. The idealized structural unit method including global nonlinearities - idealized rectangular plate and stiffened plate elements. Journal of the Society of Naval Architects of Japan. 159: 283-293 (in Japanese).

Vlasov V.Z. 1959. Thin-walled elastic bars, $2^{\text {nd }}$ Edition (in Russian). Moscow, RUS: Fizmatgiz. 
Wang C, Wu J, Wang D. 2018. Numerical investigation of three-dimensional hull girder ultimate strength envelope for an ultra large container ship. Ocean Engineering. 149: 23-37.

Wang C, Wu J, Wang D. 2019. Design similar scale model of a 10,000 TEU container ship through combined ultimate longitudinal bending and torsion analysis. Applied Ocean Research. 88: 1-14.

Yao T, Fujikubo M. 2016. Buckling and ultimate strength of ship and ship-like floating structures. Amsterdam, The Netherlands: Elsevier. 